\title{
Neurocognitive performance and behavior before and after treatment for sleep-disordered breathing in children
}

This article was published in the following Dove Press journal:

Nature and Science of Sleep

13 August 2010

Number of times this article has been viewed

\author{
Mark J Kohler' \\ Kurt Lushington ${ }^{2}$ \\ J Declan Kennedy' \\ 'Children's Research Centre, \\ University of Adelaide, \\ North Adelaide, Australia; \\ ${ }^{2}$ School of Psychology, Social Work \\ and Social Policy, University of \\ South Australia, Adelaide, Australia
}

Correspondence: Mark J Kohler Children's Research Centre, Women's and Children's Hospital, 72 King William Road, South Australia, 5006, Australia

Tel +6I $8816 \mid 7266$

Fax +6I $8816|703|$

Email mark.kohler@adelaide.edu.au

\begin{abstract}
Neurocognitive and behavioral problems are increasingly reported in children with sleep-disordered breathing (SDB). The impact of treatment for SDB on neurocognition and behavior is, therefore, an issue of increasing importance. To date, there has been little consideration given to the quality of studies when reviewing associated neurocognitive and behavioral problems in children with SDB, and furthermore, there has been little systematic review of treatment outcomes. The aim of this review was to provide an up-to-date and critical review of the current literature. Findings indicate a specific pattern of neurocognitive problems in children with SDB; however, the pattern of behavioral problems is less clear. Very few studies were found to provide a rigorous investigation of posttreatment neurocognitive and behavior outcomes. Despite this, relatively consistent improvements in global intelligence, attention, and visual spatial ability are shown; however, persistent deficits in other domains are also evident. For behavior, problems of hyperactivity, aggression or conduct problems, and somatic complaints improve following treatment. In contrast, symptoms of anxiety and social problems less consistently improve. These findings should aid in the development of more targeted investigations and well-designed studies exploring both the causative mechanisms and the treatment response for neurocognitive and behavior problems in children with SDB.
\end{abstract}

Keywords: adenotonsillectomy, neurocognition, sleep-disordered breathing, children, behavior

Obstructive sleep-disordered breathing (SDB) is common in children and varies along a continuum of upper airway obstruction from primary snoring to upper airway resistance syndrome (UARS) to obstructive sleep apnea syndrome (OSAS). Primary snoring is characterized by frequent snoring without ventilatory abnormalities or obvious sleep disruption and affects $5 \%-10 \%$ of children. UARS differs from primary snoring in that sleep is fragmented by arousals, while the severe OSAS is characterized by hypoxia and sleep fragmentation, affecting $1 \%-4 \%$ of children. ${ }^{1}$ There is now convincing evidence that SDB is associated with neurocognitive and behavioral deficits, particularly those of hyperactivity, inattention, memory, learning, executive functioning, and general cognitive capacity. ${ }^{2}$ In contrast, there is less convincing evidence that treatment of SDB (ie, adenotonsillectomy) reverses deficits. This remains to be completely investigated, as do the correlates of SDB and their association with neurocognitive and behavioral deficits.

Charles Dickens, ${ }^{3}$ in his book The Posthumous Papers of the Pickwick Club, is credited with an early description of child SDB, with the fat boy Joe often falling asleep in strange or inappropriate places and snoring when he was sleeping, as having slow perception, bizarre and aggressive behavior, being red-faced with swollen legs and 
dividing “. .. his time into small alternate allotments of eating and sleeping." Over 50 years later, William Osler ${ }^{4}$ in the 1892 edition of The Principles and Practice of Medicine presciently described a child with suspected SDB, as responding “... slowly to questions and may be sullen and cross ... The influence on the mental development is striking ... It is impossible for them to fix the attention for long at a time". Similarly, William Hill', reporting in the British Medical Journal in 1889 , noted symptoms of "... backwardness and stupidity ..." in children with adenotonsillar enlargement. Despite these seminal observations, it took another 8 decades before the impact of childhood SDB on daytime cognitive performance and behavior was formally investigated by Guilleminault et $\mathrm{al}^{6}$ in 1976. These authors reported that the majority of children with OSAS in their small sample of eight children had excessive daytime sleepiness and learning difficulties at school. Further, children attending school were reported by their teachers to be hyperactive, to be inattentive, and to have a general decrease in intellectual ability while half the children were receiving mental health intervention for "emotional problems". Despite the small sample size and lack of controls, this initial study demonstrated that children with SDB have substantive behavior and cognitive performance deficits a finding that was largely overlooked for the next 2 decades. In 1982, Guilleminault et $\mathrm{al}^{7}$ published a report of 25 snoring children who on nocturnal polysomnography (PSG) did not meet the criteria for OSAS, but demonstrated significantly increased esophageal pressure during sleep when compared with controls, suggesting UARS. Notably, these children were hyperactive (48\%), aggressive (40\%), withdrawn (40\%), and clumsy (44\%). All the school-aged children in remedial education programs were reported to have learning problems (40\%). Further, eight children were on methylphenidate treatment for hyperactivity, and 19 children had a current or previous referral to a psychiatrist or psychologist. Although only the second investigation in this area, this study indicated that even mild forms of SDB may be associated with significant behavioral and cognitive sequelae.

Until the mid-1990s, there was little additional research examining cognitive and behavior sequelae in children with SDB, with the focus only returning in the early 2000 s. A series of reviews undertaken between 2001 and 2006,8-12 have consistently identified cognitive deficits in attention, memory and learning, and general intelligence, and behavioral problems of attention, hyperactivity, and aggression, with the later reviews also including anxiety, depression, and emotional instability. However, the deficits identified in these earlier studies reflect the focus of researchers, with several domains notably absent or underexplored from examination such as sensorimotor function, language skills, and visuospatial ability. The early reviews also revealed substantial methodological limitations in the field, including inadequate sampling methods; inappropriate or inadequate statistical analysis; small sample sizes; lack of control data; inadequate methods for diagnosis of SDB status; and a failure to consider potential confounders such as socioeconomic and demographic status, obesity, family history, chronicity of disease, age, gender, comorbid disorders, ethnicity, parental education, and other environmental factors. An especially important limitation is the failure by most studies to consider the interplay between SDB, hyperactive behavior, and ADHD, the delineation of which appears to be vital in helping to clarify the unique role SDB plays in the development of hyperactive behavior. ${ }^{13}$

\section{A critical review of the literature}

Given the recent increase in research investigating the cognitive and behavioral deficits among children with SDB and the many limitations evident in this research, it is important that strict evaluation guidelines be established. A parallel need has emerged in the adult OSAS field resulting in rigorous exclusion criteria, which has enabled better characterization of the pattern of cognitive domains impacted by OSAS and identification of those cognitive domains that improve with treatment. For example, Aloia et al ${ }^{14}$ excluded studies specifically recruiting non-OSAS participants, without verification of OSAS by PSG; recruiting medical populations with OSAS, including children or adolescents and exclusively patients with central sleep apnea; and assessing a single cognitive domain or using nonvalidated instruments. In doing so, a clear pattern of spared global intelligence, but impaired attention, executive functioning, memory, and psychomotor functioning, was characterized in OSAS adults, with treatment response in all domains except in psychomotor functioning. Imposing similar exclusions and critically reviewing the current child-based literature are also likely to clarify the pattern of neurocognitive and behavioral problems and treatment response in children with SDB.

Data for the current review included empirical studies published in peer-reviewed journals up until November 2009. A literature search using PubMed and PsychInfo online databases was made using combinations of the following search terms: sleep, children, snoring, apnea, cognition, neurocognition, cognitive, behavior, and behavioral. Existing reference lists from the published studies were also reviewed to identify 
additional relevant studies. Studies with no English version, book chapters, review articles, dissertations, abstracts, letters to the editor, and any nondata analytic reports were excluded. Initially, 95 studies were identified for consideration (see Appendix A). To provide a more critical review of the literature, studies were included only if they met the following criteria:

1. SDB status was verified by overnight laboratory or homebased multichannel PSG [including at least oximetry, airflow, electrocardiogram, thoracic and abdominal movements, and video monitoring in the absence of electroencephalogram (EEG)].

2. Special medical populations with SDB were excluded (such as those with Down's syndrome or Pierre Robin sequence).

3. Study participants aged over 18 years were excluded.

4. Validated measures of neurocognitive performance (excluding school grades) and behavior were used.

5. Data of control group or standardized normative data were used while reporting group performance (except when reporting the association between SDB severity and performance).

To facilitate a better understanding of the contribution of SDB to neurocognitive and, likewise, behavioral deficits, these two broad areas have been separately examined. Twenty-eight studies that report neurocognitive findings (Table 1 ) and 21 reporting behavioral findings (Table 2) with 12 overlapping studies were included. In addition, we further separated the studies into those that have examined the association between SDB severity and neurocognition $(\mathrm{n}=13$; Table 3$)$ and between SDB and behavior $(n=12$; Table 4$)$, with seven overlapping studies.

\section{Neurocognitive performance deficits in children with SDB}

A summary of neurocognitive domains assessed by studies meeting this review's criteria is presented in Table 1. All studies report one or more neurocognitive deficits in children with $\mathrm{SDB}$, with the frequency of affected domains ranging from $40 \%$ for verbal intelligence to $71 \%$ for attention. The most frequently assessed domain was intelligence (including global, verbal, and nonverbal intelligence; 24 studies) and the least sensorimotor functioning (six studies). Most studies report significant deficits in intelligence, attention, and executive function and less commonly deficits in memory, visual-spatial ability, language skills, and sensorimotor functions. Notably, there does not appear to be a dose-response effect, with the magnitude of deficits comparable in primary snoring and OSAS.

Despite 13 of 20 studies reporting that global intelligence scores were significantly lower in children with SDB compared with controls, mean scores for children with SDB in 11 of these studies were within the normal range and less than one standard deviation below the mean in only two studies. ${ }^{10,15}$ In addition, a number of studies report the mean global intelligence scores in control groups at or above the upper limit of the normal range. ${ }^{16-19}$ It could be argued that a recruitment bias in control samples may force the difference observed in these studies; however, performance in these control samples is consistent with that of healthy children in other large studies. ${ }^{20}$ The pattern of findings for global intelligence parallels those for other neurocognitive domains, with the performance reduced in children with SDB but generally in the normal range. Of the two exceptions that report substantively reduced global intelligence quotient (IQ) scores, one study exclusively recruited children with low socioeconomic standing, while the second included children with severe SDB symptoms. Compared with children from high socioeconomic status (SES), children with low SES have worse neurocognitive performance when sleep is disturbed, but similar performance when sleep is undisturbed..$^{21}$ Low SES is also associated with an increased risk for behavioral and neurocognitive deficits among children with SDB. ${ }^{22,23}$ Taken together, these results suggest an interaction between SDB and SES, which may place subgroups of children at higher risk for neurocognitive and behavioral impairment. The results also highlight the problems of evaluating neurocognitive performance and the need to control for confounds, such as SES, in analyses.

In addition to deficits in intelligence, majority of studies also report that children with SDB have reduced executive function characterized by problems with planning and strategizing, but not with inhibition. ${ }^{10,18,24-27}$ This suggests a specific pattern of executive dysfunction among children with SDB and distinct to findings in ADHD, where deficits in inhibition are considered to be a core feature. ${ }^{28}$ The final area of consistently reduced performance in children with SDB is attention. A primary deficit in attentional capacity has been proposed to underlie both lower and higher order neurocognitive deficits in adults with OSAS. ${ }^{29}$ It is considered that attentional capacity is sensitive to sleep fragmentation and likely to be evident across the SDB spectrum. In addition, attentional capacity is considered to underpin higher order neurocognitive processes such as executive functioning. Despite the appeal of these hypotheses, the magnitude of 


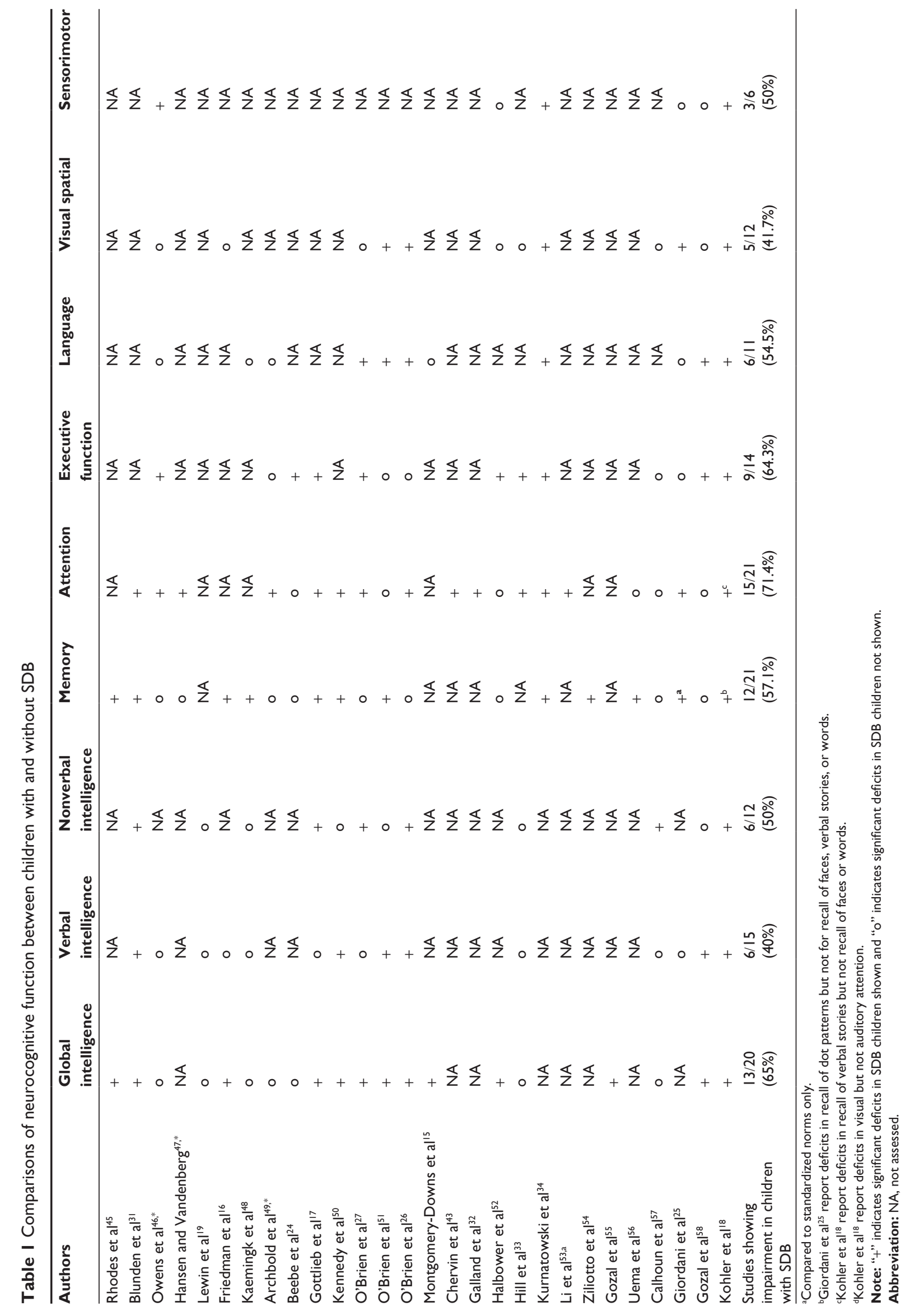


Table 2 Association of neurocognitive function with SDB severity among children

\begin{tabular}{|c|c|c|c|c|c|c|c|c|c|}
\hline Authors & $\begin{array}{l}\text { Global } \\
\text { intelligence }\end{array}$ & $\begin{array}{l}\text { Verbal } \\
\text { intelligence }\end{array}$ & $\begin{array}{l}\text { Nonverbal } \\
\text { intelligence }\end{array}$ & Memory & Attention & $\begin{array}{l}\text { Executive } \\
\text { function }\end{array}$ & Language & $\begin{array}{l}\text { Visual } \\
\text { spatial }\end{array}$ & Sensorimotor \\
\hline Rhodes et $\mathrm{al}^{45}$ & NA & NA & NA & + & NA & NA & $\circ$ & NA & NA \\
\hline Lewin et al ${ }^{19}$ & $\circ$ & + & $\circ$ & NA & NA & NA & NA & NA & NA \\
\hline $\begin{array}{l}\text { Kaemingk } \\
\text { et al }{ }^{48}\end{array}$ & + & $\circ$ & + & + & NA & NA & + & NA & NA \\
\hline $\begin{array}{l}\text { Archbold } \\
\text { et al }{ }^{49}\end{array}$ & NA & NA & NA & NA & NA & + & NA & NA & NA \\
\hline Beebe et $\mathrm{al}^{24}$ & $\circ$ & NA & NA & $\circ$ & + & + & NA & NA & NA \\
\hline $\begin{array}{l}\text { Kennedy } \\
\text { et } \mathrm{al}^{50}\end{array}$ & + & + & + & + & $\circ$ & NA & NA & NA & NA \\
\hline $\mathrm{O}^{\prime}$ Brien et $\mathrm{al}^{27}$ & + & $\circ$ & + & $\circ$ & + & + & $\circ$ & $\circ$ & NA \\
\hline Chervin et $\mathrm{al}^{43}$ & NA & NA & NA & NA & $\circ$ & NA & NA & NA & NA \\
\hline Galland et $\mathrm{a}^{32}$ & NA & NA & NA & NA & $\circ$ & NA & NA & NA & NA \\
\hline Li et $\mathrm{al}^{53}$ & NA & NA & NA & NA & + & NA & NA & NA & NA \\
\hline Suratt et $\mathrm{a}^{59}$ & + & $\circ$ & NA & $\circ$ & $\circ$ & NA & NA & $\circ$ & NA \\
\hline Calhoun et $\mathrm{al}^{57}$ & $\circ$ & $\circ$ & $\circ$ & $\circ$ & $\circ$ & $\circ$ & NA & $\circ$ & NA \\
\hline Kohler et al ${ }^{18}$ & $\circ$ & $\circ$ & $\circ$ & $\circ$ & $\circ$ & $\circ$ & $\circ$ & $\circ$ & $\circ$ \\
\hline $\begin{array}{l}\text { Studies } \\
\text { showing } \\
\text { association } \\
\text { between } \\
\text { neurocognition } \\
\text { and SDB severity }\end{array}$ & $\begin{array}{l}4 / 8 \\
(50 \%)\end{array}$ & $\begin{array}{l}2 / 7 \\
(28.6 \%)\end{array}$ & $\begin{array}{l}3 / 6 \\
(50 \%)\end{array}$ & $\begin{array}{l}3 / 8 \\
(37.5 \%)\end{array}$ & $\begin{array}{l}3 / 9 \\
(33.3 \%)\end{array}$ & $\begin{array}{l}3 / 5 \\
(60 \%)\end{array}$ & $\begin{array}{l}1 / 4 \\
(25 \%)\end{array}$ & $\begin{array}{l}0 / 4 \\
(0 \%)\end{array}$ & $\begin{array}{l}0 / 1 \\
(0 \%)\end{array}$ \\
\hline
\end{tabular}

Note: “+” indicates significant association shown and "o" indicates significant association not shown. Associations in the abovementioned studies were determined using a range of statistical techniques including Pearson correlations, Spearman's rho correlations, linear regression, logistic regression, and analysis of variance. Due to the limited number of studies and variation in sleep measures reported, SDB severity represents measures of hypoxia and/or respiratory-related arousals and/or frequency of respiratory events.

Abbreviation: NA, not assessed.

neurocognitive deficits is generally comparable in children with mild SDB (primary snoring) and children with severe SDB (OSAS).$^{18}$ In the few cases of a difference between SDB groups and contrary to expectations, children with primary snoring generally perform worse than children with OSAS. ${ }^{25}$ As a corollary, a similar pattern of finding regarding SDB severity to those reported for neurocognitive functioning is evident in behavioral functioning. ${ }^{30}$ Attentional deficits in children with SDB are typically for visual not auditory, and while generalization is limited due to the variation of tests used on balance SDB children have problems with maintaining sustained visual attention. ${ }^{10,17,18,24,26,27,31-34}$ As attention deficits have been found to mediate deficits in other neurocognitive functions among adults with $\mathrm{SDB},{ }^{29}$ it will be important for future research to investigate the interaction between attention and executive functioning as this may explain deficits in other neurocognitive domains.

\section{Associations between SDB severity and neurocognitive performance}

Only a small number of studies have examined the association between SDB severity and neurocognitive performance, and the majority of these have failed to demonstrate a significant dose-response association (Table 2). The only finding with any consistency is the reported significant associations between increased SDB severities with reduced executive function ( 3 of 5 studies). Examination of the studies revealed no obvious factors to explain why some studies have reported significant and others nonsignificant correlations.

The lack of significant associations raises concerns about the assumption of a temporal relationship between SDB severity and neurocognitive performance. Because of the relative difficulty in testing neurocognitive functioning in young children, SDB studies are typically restricted to children $>5$ years. However, the incidence of SDB symptoms peaks in preschool children, ${ }^{35}$ suggesting that children with SDB are likely to have been symptomatic for longer periods before testing. As such, it is possible that neurocognitive deficits secondary to SDB may develop in early life explaining the lack of correlation between SDB severity and neurocognitive measures found later in life. This suggests that the relationship may be more related to the age of disease onset or disease duration rather than the current SDB severity. Cumulative effects or earlier point of insult during a period of rapid neural development may result in greater severity and a range of deficits. 
Table 3 Comparisons of daytime behavior between children with and without SDB

\begin{tabular}{|c|c|c|c|c|c|c|c|c|}
\hline Authors & Inattention & Hyperactivity & Anxiety & Depression & $\begin{array}{l}\text { Aggression/ } \\
\text { oppositional }\end{array}$ & $\begin{array}{l}\text { Social } \\
\text { problems }\end{array}$ & Withdrawn & $\begin{array}{l}\text { Somatic } \\
\text { complaints }\end{array}$ \\
\hline Blunden et $\mathrm{al}^{31}$ & $\circ$ & NA & $\circ$ & $\circ$ & $\circ$ & $\circ$ & $\circ$ & $\circ$ \\
\hline Owens et $\mathrm{al}^{46, *}$ & $\circ$ & $\circ$ & $\circ$ & NA & $\circ$ & NA & NA & + \\
\hline Lewin et $\mathrm{al}^{19}$ & ० & NA & + & + & $\circ$ & + & $\circ$ & + \\
\hline Gottlieb et $a^{60}$ & + & $\circ$ & NA & NA & NA & NA & NA & NA \\
\hline Kaemingk et a ${ }^{48}$ & $\circ$ & $\circ$ & NA & NA & NA & NA & NA & NA \\
\hline Kohyama et $\mathrm{al}^{61}$ & + & NA & + & + & $\circ$ & + & + & + \\
\hline Beebe et $\mathrm{al}^{24}$ & ० & + & $\circ$ & $\circ$ & + & NA & NA & NA \\
\hline Crabtree et $\mathrm{al}^{62}$ & NA & NA & NA & + & NA & + & NA & NA \\
\hline Melendres et $\mathrm{al}^{41}$ & NA & + & NA & NA & NA & NA & NA & NA \\
\hline O'Brien et $\mathrm{al}^{27}$ & ० & $\circ$ & $\circ$ & $\circ$ & $\circ$ & ○ & $\circ$ & $\circ$ \\
\hline O'Brien et $\mathrm{al}^{51}$ & + & $\circ$ & ○ & NA & ○ & $\circ$ & NA & $\circ$ \\
\hline O'Brien et $\mathrm{al}^{26}$ & + & + & + & + & ○ & + & + & NA \\
\hline Mulvaney et $\mathrm{al}^{63}$ & + & $\circ$ & $\circ$ & $\circ$ & + & + & $\circ$ & $\circ$ \\
\hline Chervin et $\mathrm{al}^{43}$ & NA & + & NA & NA & NA & NA & NA & NA \\
\hline Galland et $\mathrm{al}^{32, *}$ & + & + & $\circ$ & + & + & $\circ$ & $\circ$ & + \\
\hline $\begin{array}{l}\text { Mitchell and } \\
\text { Kelly }{ }^{64, *}\end{array}$ & NA & $\circ$ & NA & $\circ$ & $\circ$ & NA & NA & + \\
\hline Suratt et $\mathrm{al}^{59}$ & ○ & $\circ$ & $\circ$ & NA & ○ & $\circ$ & NA & $\circ$ \\
\hline $\begin{array}{l}\text { Constantin } \\
\text { et a }\left.\right|^{65, *}\end{array}$ & $\circ$ & $\circ$ & NA & NA & $\circ$ & NA & NA & NA \\
\hline Dillon et $\mathrm{al}^{66}$ & $\circ$ & $\circ$ & $\circ$ & $\circ$ & + & NA & NA & NA \\
\hline Giordani et $\mathrm{a}^{25}$ & $+^{\mathrm{b}}$ & + & $\mathrm{O}^{\mathrm{a}}$ & NA & $t^{\mathrm{a}}$ & $t^{\mathrm{a}}$ & NA & $o^{b}$ \\
\hline Zhao et $\mathrm{al}^{30}$ & $\circ$ & $\circ$ & + & + & + & + & + & + \\
\hline $\begin{array}{l}\text { Studies } \\
\text { showing } \\
\text { impairment in } \\
\text { children with } \\
\text { SDB }\end{array}$ & $\begin{array}{l}7 / 17 \\
(41.2 \%)\end{array}$ & $\begin{array}{l}6 / 16 \\
(37.5 \%)\end{array}$ & $\begin{array}{l}4 / 14 \\
(28.6 \%)\end{array}$ & $\begin{array}{l}6 / 12 \\
(50 \%)\end{array}$ & $\begin{array}{l}6 / 16 \\
(37.5 \%)\end{array}$ & $\begin{array}{l}7 / 12 \\
(58.3 \%)\end{array}$ & $\begin{array}{l}3 / 8 \\
(37.5 \%)\end{array}$ & $\begin{array}{l}6 / 12 \\
(50.0 \%)\end{array}$ \\
\hline
\end{tabular}

Note: “+” indicates more problems in SDB children shown and "o" indicates more problems in SDB children not shown.

${ }^{a}$ Compared to standardized norms only; aPersonal communication with author and unpublished analyses.

Abbreviation: NA, not assessed.

The contention that neurocognitive deficits may occur shortly after birth in infants with SDB is supported by at least two studies. Montgomery-Downs and Gozal ${ }^{36}$ reported that in 35 healthy infants (mean age $=8.2$ months), higher snoring-associated arousal scores were associated with lower neurocognitive development scores $(r=-0.43)$. Of note, however, is that Montgomery-Downs and Gozal's study neither did include infants with OSAS in the sample nor did they differentiate between nonsnoring controls and primary snorers in their analyses, thus limiting the examination of any dose effect in the association between SDB severity and severity of neurocognitive deficits. Hunt et $\mathrm{al}^{37}$ examined the relationship between cardiorespiratory events (ie, oximetry-defined apnea) and neurocognition at 2 years of age in a combined sample of 256 healthy infants with a history of apparent life-threatening events and their siblings. Infants with $\geq 5$ compared with $<1$ "apnoeic/bradycardic" events per hour had lower mental development scores. Additional analysis of the correlations between SDB severity and neurocognitive performance by our group $^{18}$ in 46 children with SDB has revealed that correlations were stronger and significant in children aged 3-4 years, but not in 5-7 and 8-12 year olds (see Figure 1). In sum, these studies support the hypothesis that SDB in early infancy results in measurable developmental deficits.

\section{Problematic behavior in children with SDB}

In general, less than half the studies report increased problematic behavior in children with SDB (Table 3). The most frequently reported problematic behaviors were somatic complaints, depression, and social problems. This is in contrast to the widely held belief that hyperactivity, aggression or oppositional behavior, and inattention are predominant in children with SDB. The inconsistency in results combined 
Table 4 Association of behavior with SDB severity among children

\begin{tabular}{|c|c|c|c|c|c|c|c|c|}
\hline Authors & Attention & Hyperactivity & Anxiety & Depression & $\begin{array}{l}\text { Aggression/ } \\
\text { conduct }\end{array}$ & $\begin{array}{l}\text { Social } \\
\text { problems }\end{array}$ & Withdrawn & $\begin{array}{l}\text { Somatic } \\
\text { complaints }\end{array}$ \\
\hline Lewin et a $\left.\right|^{19}$ & o & NA & $\circ$ & $\circ$ & $\circ$ & $\circ$ & o & $\circ$ \\
\hline $\begin{array}{l}\text { Kohyama } \\
\text { et al }\left.\right|^{61}\end{array}$ & $\circ$ & NA & $\circ$ & $\circ$ & $\circ$ & $\circ$ & $\circ$ & $\circ$ \\
\hline Beebe et $\mathrm{a}^{24}$ & + & + & $\circ$ & + & + & NA & NA & NA \\
\hline Crabtree et $a^{62}$ & NA & NA & NA & $\circ$ & NA & $\circ$ & NA & NA \\
\hline $\begin{array}{l}\text { Melendres } \\
\text { et } \mathrm{al}^{4 !}\end{array}$ & NA & $\circ$ & NA & NA & NA & NA & NA & NA \\
\hline O'Brien et $\mathrm{al}^{27}$ & $\circ$ & $\circ$ & $\circ$ & $\circ$ & $\circ$ & $\circ$ & $\circ$ & $\circ$ \\
\hline Chervin et $\mathrm{a}^{43}$ & $\circ$ & $\circ$ & NA & NA & NA & NA & NA & NA \\
\hline Galland et a $\left.\right|^{32}$ & $\circ$ & $\circ$ & $\circ$ & $\circ$ & $\circ$ & $\circ$ & $\circ$ & $\circ$ \\
\hline Li et $\mathrm{al}^{53}$ & NA & $\circ$ & $\circ$ & $\circ$ & $\circ$ & $\circ$ & $\circ$ & $\circ$ \\
\hline Suratt et a ${ }^{59}$ & $\circ$ & $\circ$ & $\circ$ & NA & $\circ$ & $\circ$ & NA & $\circ$ \\
\hline Dillon et $\mathrm{a}^{66}$ & $\circ$ & $\circ$ & $\circ$ & $\circ$ & + & NA & NA & NA \\
\hline Zhao et al ${ }^{30}$ & $\circ$ & $\circ$ & + & + & + & + & + & + \\
\hline $\begin{array}{l}\text { Studies } \\
\text { showing } \\
\text { association } \\
\text { between } \\
\text { behavior and } \\
\text { SDB severity }\end{array}$ & $\begin{array}{l}1 / 9 \\
(11.1 \%)\end{array}$ & $\begin{array}{l}1 / 9 \\
(11.1 \%)\end{array}$ & $\begin{array}{l}1 / 9 \\
(11.1 \%)\end{array}$ & $\begin{array}{l}2 / 9 \\
(22.2 \%)\end{array}$ & $\begin{array}{l}3 / 9 \\
(33.3 \%)\end{array}$ & $\begin{array}{l}1 / 8 \\
(12.5 \%)\end{array}$ & $\begin{array}{l}1 / 6 \\
(16.7 \%)\end{array}$ & $\begin{array}{l}1 / 7 \\
(14.3 \%)\end{array}$ \\
\hline
\end{tabular}

Note: "+" indicates significant association shown and "o" indicates significant association not shown. Associations in the abovementioned studies were determined using a range of statistical techniques including Pearson correlations, Spearman's rho correlations, linear regression, logistic regression, and analysis of variance. Due to the limited number of studies and variation in sleep measures reported, SDB severity represents measures of hypoxia and/or respiratory-related arousals and/or frequency of respiratory events.

Abbreviation: NA, not assessed.

with the results of this review suggests that problematic behavior in children with SDB may be better explained by comorbid sleep problems. ${ }^{38}$ The incidence of comorbid sleep disorders in children with SDB (eg, sleep walking and night terrors) is high. ${ }^{39,40}$ This raises the importance of controlling the effect of comorbid sleep problems on behavior in future studies.

There is some evidence that children with SDB are sleepier than controls, which may contribute to increased problematic behavior. Melendres et $\mathrm{al}^{41}$ administered the Epworth Sleepiness Scale to measure the level of daytime sleepiness in 108 children with suspected SDB and 72 controls matched for age, gender, race, and SES. Children with suspected SDB were rated as sleepier and more hyperactive than controls; however, no difference in sleepiness scores was found between the children with primary snoring versus OSAS. It is noteworthy that the Epworth Sleepiness Scale is reported not to correlate with objective measures of sleepiness in children with $\mathrm{SDB},{ }^{42}$ raising the need for validation of an age-specific sleepiness scale before conclusions about such results can be drawn. Chervin et $\mathrm{al}^{43}$ used the Multiple Sleep Latency Test (MSLT) in 78 children with SDB before and after adenotonsillectomy and compared results with those of 27 controls of similar demographic status from an unrelated hospital clinic. The MSLT is reported to be sensitive to sleepiness in children from 3 years of age. ${ }^{44}$ Chervin's group found that children scheduled for adenotonsillectomy demonstrated increased SDB severity and reduced MSLT times before surgery on the day following PSG, indicating increased sleepiness.

\section{Associations between SDB severity and problematic behavior}

As with neurocognition, there is little evidence of an association between SDB severity and problematic behavior (Table 4). Only three of 12 studies report any significant association, with all three reporting that SDB severity was associated with increased aggression or oppositional behavior and two studies reporting that SDB severity was associated with increased depression. This suggests the possibility of a third factor such as sleepiness modulating the association between SDB and behavior. The two previously mentioned studies assessing sleepiness in children with SDB report significant linear correlations between SDB severity and sleepiness. ${ }^{41,43}$ Both these studies examined only a limited range of other behaviors (confined to measures of attention and hyperactivity); however, no associations of problematic behavior and SDB severity were reported. 


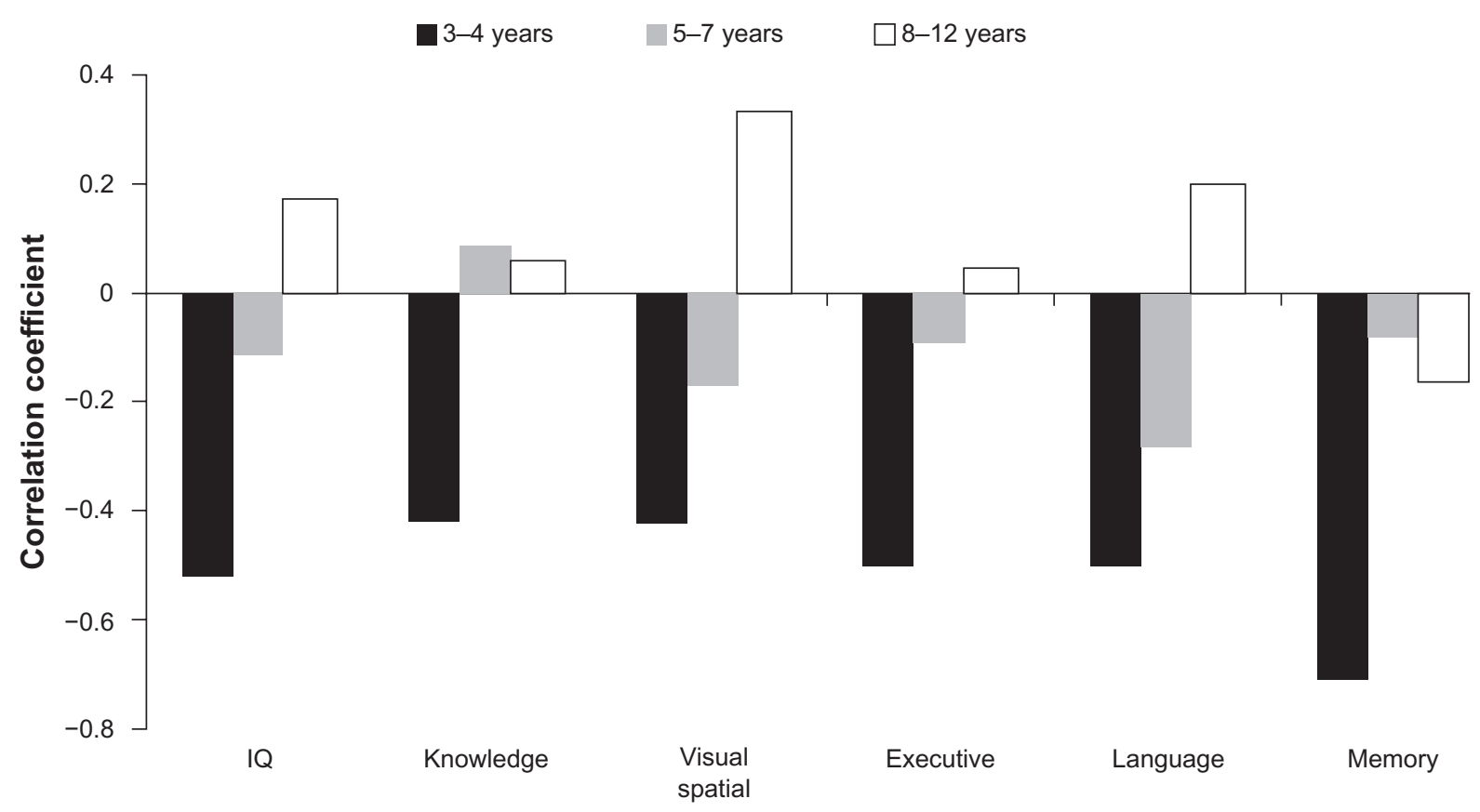

Figure I Pearson bivariate correlations $(r)$ between SDB severity (obstructive apnea and hypopnea index) and neurocognitive performance domains among children with SDB at different ages ( $n=18$ for 3-4 years, $n=13$ for $4-7$ years, and $n=13$ for $8-12$ years). For further details on study design and results see Kohler et al. ${ }^{18}$

\section{Effects of treatment on neurocognition and behavior}

Given the daytime decrements outlined earlier, there is currently great interest in demonstrating that treatment of childhood SDB reverses not only the nocturnal ventilator abnormalities but also the behavioral and neurocognitive deficits. Our review identified 30 treatment studies: 27 adenotonsillectomy studies (including two studies that compared tonsillectomy with intracapsular tonsillectomy or tonsillotomy), two tracheotomy studies, and one study that used unspecified surgery and continuous positive airway pressure (Appendix B). The impact of treatments other than adenotonsillectomy on neurocognitive and behavioral functions in children is largely unknown and is an area deserving further study. Overall, the treatment (by adenotonsillectomy) is reported to improve attention, memory, and school performance and reduce hyperactivity, aggression or oppositional behavior, inattention, somatic complaints, and anxiety.

\section{Neurocognitive performance after treatment for SDB}

One of the early proponents of adenotonsillectomy for childhood OSAS was William Osler who in 1919 said, "If the tonsils are large and the general state is evidently influenced by them they should be at once removed"; ${ }^{67}$ however, it was not until the 1970s that researchers began examining its effect on neurocognitive functioning. Early studies of treatment for SDB in children are anecdotal in nature, but all report improved neurocognitive and behavioral functioning. For example, in the landmark study by Guilleminault et $\mathrm{al}^{6}$ adenotonsillectomy reduced daytime sleepiness and improved school performance in all eight children and normalized academic performance in three of five children experiencing learning difficulties. In 1982, Guilleminault et $\mathrm{al}^{7}$ again demonstrated that adenotonsillectomy led to improved school performance in all cases 3 months postsurgery. Before treatment, all children with SDB were placed in remedial school classes and only two remained in these classes for 6 months after treatment. Tiredness was also reduced as measured by MSLT scores. In the same year, Brouillette et $\mathrm{l}^{68}$ reported five of 22 children with SDB, behavioral disturbance, excessive sleepiness, and developmental delay. All demonstrated improved daytime functioning following surgical treatment.

From 1990 to 1996, results from a series of studies conducted at the Osler Chest Unit in Oxford demonstrated improved questionnaire-based reports of attention and vigilance, following either adenotonsillectomy for SDB or spontaneous resolution of snoring. ${ }^{69-71}$ In 1998, Gozal ${ }^{72}$ confirmed the benefits of adenotonsillectomy in a large sample of children recruited from a community rather than a hospital's sleep clinic. In an innovative study, he examined the academic performance in 297 first-grade children who ranked in the lowest $10 \%$ of their class and identified 
54 children with SDB (confirmed by overnight oximetry and monitoring of transcutaneous partial pressure of carbon dioxide). Of this subset, 24 underwent adenotonsillectomy and by second grade demonstrated improved academic performance compared with both untreated children and children without evidence of SDB, but who also performed in the lowest $10 \%$ of their class. Two years later, another group reported improved daytime sleepiness and school performance among 45 children aged $2.5-15.5$ years, following removal of adenoids and/or tonsils for OSAS confirmed by $\mathrm{PSG}^{73} \mathrm{~A}$ number of reviews have since confirmed the benefits of adenotonsillectomy as a treatment for upper airway obstruction, estimating that ventilatory function is normalized in on average $66 \%$ to $83 \%$ of cases following surgery ${ }^{74,75}$ and, likewise, postadenotonsillectomy gains in neurocognitive and behavioral performance. ${ }^{76,77}$ However encouraging, the interpretation of the literature needs to be treated with caution as few studies have adequately addressed methodological limitations especially assessing children with PSG at follow-up and lack of control data. As outlined in recent studies, it is estimated that up to $33 \%$ of children on average continue to obstruct postadenotonsillectomy, potentially confounding postoperative comparisons. As well, without a control group it is difficult to exclude learning effects, which may explain treatment gains, particularly if there is a short time between testing. After applying the strict criteria described earlier, we were able to include only two studies examining the impact of adenotonsillectomy on neurocognitive function ${ }^{18,43}$ and two studies examining the impact on behavior ${ }^{43,66}$ in this review. Below is a brief discussion on relevant treatment studies, followed by the results of this review for neurocognitive and behavior functions.

A range of neurocognitive and behavior functions were assessed by Owens et a ${ }^{46}$ in 18 children with OSAS. Eight of these children subsequently underwent adenotonsillectomy and were reassessed 6-12 months postsurgery. Tests of executive function (verbal fluency) were improved following surgery. Although no significant change in general neurocognitive ability, language skill, memory, visual perception, motor ability, or behavior was observed, effect sizes were reported to be large for tests of attention and visualmotor ability. Hansen and Vandenberg ${ }^{47}$ examined another small group of children with OSAS and demonstrated that memory performance was improved 5 months after treatment. Improvements in visual attention and general neurocognitive performance approached statistical significance in this study; however, auditory attention (which was rated as impaired in comparison to normative data before treatment) remained unchanged. In 2003, Friedman et $a{ }^{16}$ assessed neurocognitive function using standardized tests in 39 children with OSAS compared with 20 controls. Twenty-seven children with OSAS and 14 controls were reassessed 6-10 months after adenotonsillectomy. Significant improvement was seen in treated children for perceptual ability, concept formation, verbal and spatial memory, analytical thinking, and total intelligence. No improvement was seen for vocabulary and memory for numbers. Avior et $\mathrm{al}^{79}$ assessed attention in 19 children with SDB before and 2 months after adenotonsillectomy. Attention improved in all except one participant postoperatively, demonstrating that neurocognitive changes may occur within the first 2 months after treatment; however, the potential impact of a learning effect needs to be considered.

In the first study to examine preschool children, Harvey et $\mathrm{al}^{80}$ assessed mental ability in 24 children with OSAS before and 6 months after adenotonsillectomy. Results were compared with 15 age- and gender-matched children with OSAS but who did not receive any intervention. Adenotonsillectomy did not result in any change in mental ability scores and no between-group differences were observed, raising questions about the optimal timing of treatment to prevent daytime deficits. In 2005, MontgomeryDowns et $\mathrm{al}^{15}$ compared data from 19 preschool children with OSAS to 19 matched nonsnoring controls on measures of general intellectual ability, language development, and memory at baseline and 3-6 months postadenotonsillectomy for those with OSAS. At baseline, general intellectual ability was lower in OSAS children and improved in 16 children postoperatively. No group differences were found pre- or postsurgery for measures of memory and language; however, executive function performance was impaired in OSAS subjects both before and after treatment. Combined, these results suggest that general neurocognitive ability and executive deficits are evident among preschool-aged children with OSAS, and some of these deficits may not be remediated 3-6 following treatment.

Galland et $\mathrm{al}^{32}$ report objective measures of sustained attention and parental reports of behavior in 61 children with suspected SDB pre- and 3-months postsurgery. Visual continuous performance testing revealed increased inattention and impulsivity among children before surgery and significant improvement following adenotonsillectomy. In contrast, performance on an auditory continuous performance test showed no significant deviation from normative data and no change postsurgery. Similarly, Li et al ${ }^{53}$ assessed attention and impulsivity among 40 children with suspected SDB before 
and 6 months following adenotonsillectomy. Response time and indications of ADHD were improved postoperatively; however, there was no significant association between change in SDB severity and change in test scores. In an assessment of cerebral blood flow and neurocognition in children with mild SDB compared with controls, Hogan et $\mathrm{al}^{81}$ found some evidence of improved processing speed and visual attention among children with SDB; however, measures of executive function remained in deficit postadenotonsillectomy. Using anecdotal parental report of neurocognitive performance and behavior, Moré et $\mathrm{al}^{82}$ found a large proportion of parents of 44 children with SDB reported resolved problems of speech delay, poor school performance, poor concentration, and poor memory. More recently, Lundeborg et al ${ }^{83}$ reported that language deficits (phonological processing) were improved following both tonsillectomy and partial resection (tonsillotomy) in preschool-aged children with SDB; however, deficits compared with controls were still evident at 6 months following treatment.

In one of only two studies to meet the inclusion criteria set for this review, Chervin et $\mathrm{al}^{43}$ compared measures of behavioral hyperactivity, psychiatric morbidity, sleepiness, and test of attention between 78 children scheduled for adenotonsillectomy and 27 children for unrelated surgery (77 vs 23 at follow-up). One year after surgery, children who underwent adenotonsillectomy demonstrated improvement in attention deficits and reduction in sleepiness to levels equivalent to controls. No association between attention and any PSG variable was observed; however, sleepiness (as assessed on MSLT) was significantly associated with multiple indications of SDB, including apnea index and oxygen saturation nadir. Controls in this study included cases demonstrating clinically significant levels of SDB, and these results may, therefore, not truly represent the differential neurocognitive and behavioral aspects of children with and without SDB. In contrast, in the only other study meeting the inclusion criteria, Kohler et $\mathrm{al}^{18}$ found wide-ranging neurocognitive deficits primarily in global intelligence; planning; working memory; and memory for narrative, visual attention, and language development among 44 children with SDB both at baseline and 6 months following adenotonsillectomy compared with 48 controls. It may be that deficits take longer than 6 months to normalize, but these findings raise concerns regarding the permanency of deficits.

Despite the pattern of treatment response for a number of neurocognitive performance domains in children with SDB, residual deficits in memory, executive functioning, and language development are also evident. In addition, only two studies met the strict inclusion criteria used in this review (which emphasized valid assessment of SDB severity, neurocognitive performance, and inclusion of control data at baseline and follow-up assessments), themselves presenting contrasting results. Clearly, further well-controlled treatment studies are required before informed decisions about treatment efficacy for remediating neurocognitive deficits can be made.

\section{Behavior after treatment for SDB}

Although commonly reported in the positive, relatively few studies have examined whether problematic behavior is reduced in children with SDB following treatment. In 1982, Guilleminault et $\mathrm{al}^{7}$ reported that the behavior improved 3-months postadenotonsillectomy and by 6 months none of the eight children with SDB previously taking methylphenidate for hyperactivity were still medicated. Brouillette et al ${ }^{68}$ also reported reduced hyperactivity, reduced aggression, and reduced daytime sleepiness following surgical treatment for SDB among five children. Goldstein et a ${ }^{84,85}$ demonstrated in a combined cohort of 79 children that adenotonsillectomy improved anxiety, depression, thought problems, and total problematic behavior; however, reports of improvements in withdrawn behavior, somatic complaints, and attention problems were inconsistent. Mitchell and Kelly ${ }^{64}$ assessed behavior in 23 children with OSAS and reported postadenotonsillectomy improvements at 6 months and again at 9-18 months in aggression, hyperactivity, somatic complaints, depression, and atypicality. Galland et $\mathrm{al}^{32}$ report in 61 children with SDB that adenotonsillectomy reduced hyperactivity, aggression, depression, somatic complaints, attention problems, and composite scores for internalizing, externalizing, and total problems. Roemmich et $\mathrm{al}^{86}$ report reduced hyperactivity in 54 children with OSAS 12 months postadenotonsillectomy. Apart from problems of aggressive behavior, Li et $\mathrm{al}^{53}$ also report in 40 children with SDB substantial reduction in a broad range of internalizing and externalizing behavior problems 6 months following adenotonsillectomy. Wei et al ${ }^{87,88}$ completed a 6-month and a 2.4- to 3.6-year follow-up of 71 and 44 children with SDB, respectively, and reported postadenotonsillectomy improvement in inattention, hyperactivity, and oppositional behavior. Moré et $\mathrm{al}^{82}$ report that aggressiveness and hyperactivity were reduced 9 months after adenotonsillectomy, while Ericsson et al ${ }^{89}$ report reduced somatic complaints following either tonsillotomy or tonsillectomy in 67 children with SDB; mixed results for symptoms of aggression, anxiety, inattention, and social problems; and no change for withdrawn behavior and thought 
problems. In contrast, Constantin et $\mathrm{al}^{65}$ report no gains postadenotonsillectomy compared with retrospective ratings of behavior. Tran et $\mathrm{al}^{78}$ compared behavior in 42 children pre- and postadenotonsillectomy for OSAS and 41 children undergoing unrelated surgery. The authors report that children with OSAS demonstrated a greater improvement than controls in thought problems, somatic complaints, internalizing behaviors, and total behavioral problems. Despite the encouraging results, and similar to the caveats noted for the neurocognitive studies, relatively few of the studies examining the impact of adenotonsillectomy on behavior have included PSG and control data at follow-up.

Both studies to assess behavior response to treatment and meet the inclusion criteria in this review are from the same sample of children. Chervin et $\mathrm{al}^{43}$ found that before adenotonsillectomy, 78 children with SDB were rated as more hyperactive and more likely to have attention-deficit or hyperactivity disorder compared with 23 controls. One year after surgery, children who underwent adenotonsillectomy demonstrated hyperactivity levels equivalent to controls. Dillon et $\mathrm{al}^{66}$ found reduced oppositional behavior in children with SDB, but found problems with anxiety and depression following treatment.

Largely consistent with previous reviews, reductions in hyperactivity, aggression or oppositional behavior, and somatic complaints seem evident following treatment for SDB. There is also some evidence to suggest that the closelyrelated symptoms of depression and withdrawn behavior are reduced posttreatment. In contrast, the evidence that parentally reported inattention and anxiety improves after treatment is less convincing.

\section{Possible mechanisms}

It is generally believed that the neurocognitive and behavioral deficits seen in children with OSAS are due to intermittent nocturnal hypoxia or fragmentation of sleep and that the failure to normalize these daytime deficits postadenotonsillectomy is secondary to the failure either to adequately correct fragmentation or hypoxia or to correct a persisting neurological dysfunction. A major difficulty for research in this area is that there is little correlation between the findings on PSG, such as cortical arousals and apnea or hypopnea indices, and changes in neurocognition or behavior. ${ }^{90}$ In addition, as daytime deficits are seen in children with mild upper airway obstruction, it is likely that explanatory polysomnographic changes will be subtle. The investigation of the etiology of these neurocognitive and behavioral deficits, therefore, requires a focus on more sensitive methods of evaluating sleep fragmentation and the effects of intermittent hypoxia on cerebral molecular structure and function.

As fragmentation of sleep by upper airway obstructioninduced arousals is less frequent in childhood OSAS, attention has been focused on more detailed evaluation of their sleeping EEG. The cyclic alternating pattern (CAP) is a measure of sleep microstructure, quantifying phasic EEG activity across the night to derive an estimate of sleep stability and fragmentation. ${ }^{91}$ A1 phase frequency of CAP (a protective reaction of the sleeping brain) has been shown to be reduced in children with $\mathrm{SDB}^{92}$ and $\mathrm{A} 2$ phases (mild cortical activation) increased among children with OSAS compared with controls. ${ }^{93}$ A rebound in A1 indices was observed among children with OSAS 1 year after rapid maxillary expander treatment; however, other measures such as A2 frequency remained unchanged. ${ }^{94}$ The functional significance of these differences is yet to be determined as is the association with neurocognitive performance and behavior. An initial study in children with Asperger syndrome has found strong correlations between neurocognitive performance, behavior, and a number of CAP indices, providing encouraging results for future investigation in children with SDB. ${ }^{95}$

Chervin et $\mathrm{al}^{96}$ quantified variations in EEG power frequencies with the respiratory cycle in children with SDB [called the "respiratory cycle - related EEG changes" (RCREC)]. Changes in RCREC were associated with subjective sleepiness in children with $\mathrm{SDB},{ }^{97}$ and postoperative changes in RCREC correlated more strongly with changes in daytime sleepiness and attention compared with changes in apnea and hypopnea frequency. ${ }^{98}$ This suggests that more detailed evaluation of sleeping EEG recordings in children using these new methods may yield new information on the association between functional EEG changes and daytime deficits.

Intermittent hypoxia results in oxidative stress and induces a proinflammatory response. In animal models this leads to apoptosis and disorganization in cerebral regions which underpin learning and memory. Neuroimaging studies in adults with SDB demonstrate a range of cerebral abnormalities including reduced hippocampal volume; frontal white matter abnormalities among SDB patients at greater risk of vascular disease; changes to motor, sensory, and autonomic control regions of the brain during wakefulness; absence of prefrontal activation in association with poor working memory performance; and compensatory recruitment of brain regions during a verbal learning test. ${ }^{99-102}$ In addition, cerebral blood flow is altered during sleep and wakefulness among adults with OSAS compared with controls. ${ }^{103,104}$ 
Elevated levels of inflammatory cytokines (proteins known to mediate inflammation, brain injury repair, neural development, and autoimmune response) and reactive oxygen species in response to hypoxia and/or sleep fragmentation have been demonstrated in adults with SDB. ${ }^{105-107}$ Studies among adults with OSAS also suggest that the upregulation of cytokines is associated with symptoms of depression, fatigue, and daytime sleepiness. ${ }^{106}$ Increased inflammatory markers among children with SDB have been reported in some studies ${ }^{108-112}$ but not others. ${ }^{113,114}$ Rodent models suggest that increased oxidative stress and upregulation of proinflammatory cytokines and inducible nitric oxide synthase (iNOS) are important contributors to both hippocampal and cortical apoptosis. ${ }^{115-117}$ Zhan et al ${ }^{118}$ recently demonstrated that the pharmacological inhibition of iNOS or genetic ablation of the enzyme in mice was associated with markedly reduced brain oxidative injury. Also, using a rodent model, animals exposed to intermittent hypoxia have been shown to demonstrate increased oxidative stress within neural tissue and reduced spatial learning compared with animals exposed to room air only or those exposed to intermittent hypoxic conditions but receiving antioxidants to prevent oxidative cellular damage. ${ }^{119}$

These findings have led to interest in the evaluation of the neurochemical and structural changes in OSAS, particularly in structures such as the hippocampus and prefrontal cortex, which underpin many of the functional neurobehavioral deficits shown. Using voxel-based morphometry, Macey et al ${ }^{120}$ demonstrated changes in gray matter concentration across multiple brain regions including the hippocampus and frontal cortex in 21 adults with OSAS compared with controls, a finding supported by Morrell et al ${ }^{121}$ who reported a loss of gray matter concentration in the left hippocampus of seven adults with OSAS. A more recent study from Macey et al ${ }^{122}$ outlined extensive white matter changes particularly in brain regions previously shown to be functionally or anatomically affected in adults with OSAS (hippocampus and amygdala, frontal, parietal, and temporal cortices). Thus, there is evolving and compelling evidence that brain structure is altered in adults with OSAS. The picture is less clear in children as few such studies have been completed.

Using proton magnetic resonance spectroscopic imaging, Halbower et $\mathrm{al}^{52}$ in a subset of six children with severe OSAS (mean OAHI, 37.8), demonstrated a significant decrease of the mean neuronal metabolite ratio $\mathrm{N}$-acetyl aspartate/choline in both the left hippocampus and the right frontal cortex, indicating metabolic disturbance and possible neuronal loss. The authors speculate that untreated OSAS could permanently alter the child's developmental and academic potential. Hill et a ${ }^{33}$ demonstrated increased cerebral blood flow velocity in children with SDB, possibly indicating increased cerebral blood flow secondary to increased metabolic demand and/or narrowing of blood vessels. Although values were not directly associated with SDB severity or executive function performance and processing speed, differences between SDB children and controls for performance on neuropsychological tasks were reduced when controlling for blood flow velocity. Following treatment, the same group was able to demonstrate a reduction in cerebral blood flow among children with SDB. This occurred despite continued deficits in executive functioning. ${ }^{81}$

A recent series of studies has postulated that individual differences in systemic inflammatory response to hypoxia (and/or sleep fragmentation) may explain differential outcomes to SDB in children. ${ }^{55,58,123}$ Levels of the inflammatory marker, high-sensitivity C-reactive protein (hsCRP), were higher among children with OSAS compared with both controls and snorers, while global neurocognitive ability was reduced in the OSAS group. Of note, a subgroup of snoring children with reduced neurocognitive scores also demonstrated elevated hsCRP levels. Furthermore, children with OSAS and lower neurocognitive scores demonstrated elevated hsCRP levels compared with matched children with OSAS and normal neurocognitive scores. ${ }^{55} \mathrm{~A}$ second study found lower plasma concentrations of the neuroprotective insulin-like growth factor-1 in children with OSAS and neurocognitive deficits compared with children with OSAS and normal neurocognitive functioning. ${ }^{58}$ Although at least one study has shown improvement in inflammatory markers among children with SDB following treatment, ${ }^{124}$ it is not known whether related improvements in neurocognitive function follow. Finally, apparent individual susceptibility may, at least in part, be genetically determined. A familial aggregation of SDB in children has been reported, suggesting increased SDB risk to be at least in part a heritable trait. ${ }^{125,126}$ Recently, the chromosomal region containing the apolipoprotein $\mathrm{E}$ (ApoE) gene has been implicated as a disease susceptibility locus for $\mathrm{SDB}^{127}$ This result has been confirmed in child $\mathrm{SDB}^{123,128}$ and, in addition, it was found that children with both SDB and neurocognitive deficits demonstrated greatest expression of the ApoE \&4 allele (presumably resulting in reduced neuroprotection). Investigation of the genetic underpinnings of SDB is extremely limited to date, and hence, further studies mapping target gene regions are required. 
Irrespective of the specific causal pathway of neurocognitive and behavioral deficits in children with SDB, the age of SDB onset is a potential moderator of residual deficits. Cumulative effects or earlier point of insult during a period of rapid neural development may result in greater severity and range of deficits. Studies of cortical maturation suggest that the neuronal overproduction and subsequent pruning throughout childhood develop in parallel to a range of neurocognitive milestones. ${ }^{129-131}$ Neuronal insults in childhood are assumed to result in less structural and functional deficits compared with adults due to the brain's ability to compensate or modify by taking advantage of such neuronal overproduction and subsequent alternate synaptic pathways. Proponents of this idea point to the evidence from good outcomes for children with focal neuronal insults. ${ }^{132,133}$ Others argue that this same increased interconnectivity combined with brain immaturity and limited established neurocognitive skills may place younger children at increased risk of functional and cumulative deficits following brain insults. ${ }^{134}$ In the latter case, it is considered that unless a certain function is learned during a critical or sensitive period of development, the function in question will be permanently lost or disadvantaged. Chugani ${ }^{135}$ has demonstrated that dramatic increases in brain metabolism occur between the ages of 1 and 4 years and that the high levels of metabolism are maintained up until 9-10 years. The author suggest that repeated activation of certain neuronal circuits during this period (by practice at tasks dependent on such circuits) results in stabilization of those circuits and that attempts after this time may be too late for promotion of such stabilization. One would expect that this period of increased metabolic activity represents the overlay of multiple pathways each subserving different neurocognitive functions. Coincident with this, we see an increased potential for plasticity, together supporting efforts to stabilize specific functions while the opportunity exists. Disruption of processes important for neuronal metabolism among children with SDB by increased inflammation, vascular responsiveness, and reduced opportunity for consolidation of learning may lead to long-term deficits depending on the timing of illness and treatment.

In addition to the timing of SDB onset and treatment, interindividual differences in cortical development may cause additional variation in the timing of sensitive periods for specific neurocognitive domains and subsequent vulnerability for neurocognitive deficits. Cortical growth has been shown to follow varying trajectories in children with different levels of intelligence. ${ }^{136}$ It is suggested that due to the later structural and metabolic maturation of the frontal and prefrontal cortex in more intelligent children and the prolonged phase of this maturation, an extended critical period of neurocognitive development might be afforded to such children. Consistent with this notion, Mahone et a ${ }^{137}$ found that children with ADHD and above-average IQ scores performed no worse on tests of executive function than controls with an equivalent IQ. In contrast, children with ADHD and average IQ scores demonstrated worse performance compared with IQ equivalent controls. Adults with SDB and high intelligence demonstrated attention and alertness performance equivalent to high-intelligence controls. In contrast, patients with average intelligence demonstrated reduced attention and alertness performance compared with average-intelligence controls. ${ }^{138}$ High intelligence may serve to prevent clinical impairment by providing greater reserve of neurocognitive function to compensate for neuronal insults, and in doing so suggests that increased neuronal plasticity plays an important part within the context of sensitive periods of neurocognitive development. This is yet to be evaluated among children with SDB.

\section{Conclusion}

Our critical review of neurocognition and behavior in children with SDB before and after treatment suggests firstly that before treatment, children with any degree of SDB demonstrate neurocognitive impairment compared with controls or standardized norms. This impairment is most apparent for domains highly dependent on frontal - cortical processes including executive function, attention, subsequent general intellectual ability, and to a lesser extent language development. However, compared with control samples the reductions in general intelligence are typically within the normal range. Associations with SDB severity support the concept of a direct impact of SDB on frontal cortical functions as SDB severity was most consistently correlated with reduced executive function; however, the role of nonspecific sleep disruption and the potential mediating role of attention and/or executive deficits are yet to be investigated among children with SDB. Secondly, the pattern of behavioral problems among children with SDB is less clear. A number of studies report problematic behavior in children with SDB; however, such problems are evident in less than half of the studies included. In contrast to the previous reports, evidence from well-conducted studies does not indicate inattentiveness and hyperactivity to be more prevalent than other problematic behaviors such as depression, somatic complaints, and social problems. Significant associations between behavior and SDB severity are evident in a very few studies, suggesting 
that other mediating factors related to general sleep disruption such as daytime sleepiness are at play in regulating behavior among children with SDB.

Of the treatment studies to date, the majority assess treatment effects among primary school-aged children with little follow-up data extending beyond 1 year. In addition, only a very small number of studies assess preschool-aged children, a period of life deemed critical in neurocognitive development. The key finding from treatment studies is that very few studies provide follow-up PSG to quantify posttreatment SDB severity, and similarly few studies include control data at both baseline and follow-up time points, making it difficult to establish clear patterns of treatment response. From the wider literature, neurocognitive performance improvements in global intelligence, attention, and visual-spatial ability are relatively consistent. In contrast, deficits in language and short-term memory appear to persist. Little data are available to determine whether improvements in executive deficits are likely. For behavior, problems of hyperactivity, aggression or conduct problems, and somatic complaints improve following adenotonsillectomy. In contrast, symptoms of anxiety and reported social problems do not appear to improve. Despite the reported behavior improvements, baseline reports often suggest no clinically significant problem.

The characterization of the pattern of neurocognitive deficits and problematic behavior in children with SDB provided by this review will aid in the development of more targeted investigations and well-designed studies exploring both the causative mechanisms and the treatment response. A number of theoretical models have been put forward, which require substantiation in well-designed studies if we are to delineate the pathways linking SDB to neurocognitive deficits and to understand the failure in some cases for neurocognitive deficits to resolve with treatment. In addition, the timing of intervention in children and consideration of individual development may also contribute to variations in treatment efficacy. Given the high prevalence of child SDB reported in the community and the potential long-term impact on the quality of life and health, and an individual's academic and occupational success, further investigations and development of effective strategies to identify the symptoms early and prevent residual deficits are needed.

\section{Acknowledgments}

The authors would like to thank Dr Cameron van den Heuvel and Dr James Martin for their contribution to this review, and Professor Bruno Giordani ${ }^{25}$ for providing additional analyses from his study.

\section{Disclosure}

The authors report no conflicts of interest in this work.

\section{References}

1. Lumeng JC, Chervin RD. Epidemiology of pediatric obstructive sleep apnea. Proc Am Thorac Soc. 2008;5(2):242-252.

2. Beebe DW. Neurobehavioral morbidity associated with disordered breathing during sleep in children: a comprehensive review. Sleep. 2006;29(9):1115-1134.

3. Dickens C. The Posthumous Papers of the Pickwick Club. London, UK: Chapman and Hall; 1837.

4. Osler W. Chronic tonsillitis. The Principles and Practice of Medicine. New York, NY: Appleton and Co; 1892:335-339.

5. Hill W. On some causes of backwardness and stupidity in children. BMJ. 1889;2:711-712.

6. Guilleminault C, Eldridge FL, Simmons FB, Dement WC. Sleep apnea in eight children. Pediatrics. 1976;58(1):23-30.

7. Guilleminault C, Winkle R, Korobkin R, Simmons B. Children and nocturnal snoring: evaluation of the effects of sleep related respiratory resistive load and daytime functioning. Eur J Pediatr. 1982; 139(3):165-171.

8. Bass JL, Corwin M, Gozal D, et al. The effect of chronic or intermittent hypoxia on cognition in childhood: a review of the evidence. Pediatrics. 2004;114(3):805-816.

9. Blunden S, Lushington K, Kennedy D. Cognitive and behavioural performance in children with sleep-related obstructive breathing disorders. Sleep Med Rev. 2001;5(6):447-461.

10. Halbower AC, Mahone EM. Neuropsychological morbidity linked to childhood sleep-disordered breathing. Sleep Med Rev. 2006;10(2): $97-107$.

11. Mitchell RB, Kelly J. Behavior, neurocognition and quality-of-life in children with sleep-disordered breathing. Int J Pediatr Otorhinolaryngol. 2006;70(3):395-406.

12. Ebert CS Jr, Drake AF. The impact of sleep-disordered breathing on cognition and behavior in children: a review and meta-synthesis of the literature. Otolaryngol Head Neck Surg. 2004;131(6):814-826.

13. O'Brien LM, Holbrook CR, Mervis CB, et al. Sleep and neurobehavioral characteristics of 5- to 7-year-old children with parentally reported symptoms of attention-deficit/hyperactivity disorder. Pediatrics. 2003;111(3):554-563.

14. Aloia MS, Arnedt JT, Davis JD, Riggs RL, Byrd D. Neuropsychological sequelae of obstructive sleep apnea-hypopnea syndrome: a critical review. J Int Neuropsychol Soc. 2004;10(5):772-785.

15. Montgomery-Downs HE, Crabtree VM, Gozal D. Cognition, sleep and respiration in at-risk children treated for obstructive sleep apnoea. Eur Respir J. 2005;25(2):336-342.

16. Friedman BC, Hendeles-Amitai A, Kozminsky E, et al. Adenotonsillectomy improves neurocognitive function in children with obstructive sleep apnea syndrome. Sleep. 2003;26(8):999-1005.

17. Gottlieb DJ, Chase C, Vezina RM, et al. Sleep-disordered breathing symptoms are associated with poorer cognitive function in 5-year-old children. J Pediatr. 2004;145(4):458-464.

18. Kohler MJ, Lushington K, van den Heuvel CJ, Martin J, Pamula Y, Kennedy D. Adenotonsillectomy and neurocognitive deficits in children with sleep disordered breathing. PLoS One. 2009;4(10):e7343.

19. Lewin DS, Rosen RC, England SJ, Dahl RE. Preliminary evidence of behavioural and cognitive sequelae of obstructive sleep apnea in children. Sleep Med. 2002;3:5-13.

20. Waber DP, De Moor C, Forbes PW, et al. The NIH MRI study of normal brain development: performance of a population based sample of healthy children aged 6 to 18 years on a neuropsychological battery. J Int Neuropsychol Soc. 2007:1-18.

21. Buckhalt JA, El-Sheikh M, Keller P. Children's sleep and cognitive functioning: race and socioeconomic status as moderators of effects. Child Dev. 2007;78(1):213-231. 
22. Chervin RD, Clarke DF, Huffman JL, et al. School performance, race, and other correlates of sleep-disordered breathing in children. Sleep Med. 2003;4(1):21-27.

23. Montgomery-Downs HE, Jones VF, Molfese VJ, Gozal D. Snoring in preschoolers: associations with sleepiness, ethnicity, and learning. Clin Pediatr (Phila). 2003;42(8):719-726.

24. Beebe DW, Wells CT, Jeffries J, Chini B, Kalra M, Amin R. Neuropsychological effects of pediatric obstructive sleep apnea. $J$ Int Neuropsychol Soc. 2004;10(7):962-975.

25. Giordani B, Hodges EK, Guire KE, et al. Neuropsychological and behavioral functioning in children with and without obstructive sleep apnea referred for tonsillectomy. J Int Neuropsychol Soc. 2008; 14(4):571-581.

26. O’Brien LM, Mervis CB, Holbrook CR, et al. Neurobehavioral implications of habitual snoring in children. Pediatrics. 2004;114(1):44-49.

27. O'Brien LM, Mervis CB, Holbrook CR, et al. Neurobehavioral correlates of sleep-disordered breathing in children. J Sleep Res. 2004;13(2):165-172.

28. Wodka EL, Mahone EM, Blankner JG, et al. Evidence that response inhibition is a primary deficit in ADHD. J Clin Exp Neuropsychol. 2007;29(4):345-356.

29. Verstraeten E, Cluydts R, Pevernagie D, Hoffmann G. Executive function in sleep apnea: controlling for attentional capacity in assessing executive attention. Sleep. 2004;27(4):685-693.

30. Zhao Q, Sherrill DL, Goodwin JL, Quan SF. Association between sleep disordered breathing and behavior in school-aged children: The Tucson Children's Assessment of Sleep Apnea Study. Open Epidemiol J. 2008;1:1-9.

31. Blunden S, Lushington K, Kennedy D, Martin J, Dawson D. Behavior and neurocognitive performance in children aged 5-10 years who snore compared to controls. J Clin Exp Neuropsychol. 2000;22(5):554-568.

32. Galland BC, Dawes PJ, Tripp EG, Taylor BJ. Changes in behavior and attentional capacity after adenotonsillectomy. Pediatr Res. 2006;59(5) 711-716.

33. Hill CM, Hogan AM, Onugha N, et al. Increased cerebral blood flow velocity in children with mild sleep-disordered breathing: a possible association with abnormal neuropsychological function. Pediatrics. 2006;118(4):e1100-e1108.

34. Kurnatowski P, Putynski L, Lapienis M, Kowalska B. Neurocognitive abilities in children with adenotonsillar hypertrophy. Int $J$ Pediatr Otorhinolaryngol. 2006;70(3):419-424.

35. Marcus CL. Sleep-disordered breathing in children. Am J Respir Crit Care Med. 2001;164(1):16-30.

36. Montgomery-Downs HE, Gozal D. Snore-associated sleep fragmentation in infancy: mental development effects and contribution of secondhand cigarette smoke exposure. Pediatrics. 2006;117(3):e496-e502.

37. Hunt CE, Corwin MJ, Baird T, et al. Cardiorespiratory events detected by home memory monitoring and one-year neurodevelopmental outcome. J Pediatr. 2004;145(4):465-471.

38. Blunden SL, Beebe DW. The contribution of intermittent hypoxia, sleep debt and sleep disruption to daytime performance deficits in children: consideration of respiratory and non-respiratory sleep disorders. Sleep Med Rev. 2006;10(2):109-118.

39. Goodwin JL, Kaemingk KL, Fregosi RF, et al. Parasomnias and sleep disordered breathing in Caucasian and Hispanic children - the Tucson Children's Assessment of Sleep Apnea Study. BMC Med. 2004;2:14

40. Guilleminault C, Palombini L, Pelayo R, Chervin RD. Sleepwalking and sleep terrors in prepubertal children: what triggers them? Pediatrics. 2003;111(1):e17-e25.

41. Melendres MC, Lutz JM, Rubin ED, Marcus CL. Daytime sleepiness and hyperactivity in children with suspected sleep-disordered breathing. Pediatrics. 2004;114(3):768-775.

42. Chervin RD, Aldrich MS. The Epworth Sleepiness Scale may not reflect objective measures of sleepiness or sleep apnea. Neurology. 1999;52(1):125-131.
43. Chervin RD, Ruzicka DL, Giordani BJ, et al. Sleep-disordered breathing, behavior, and cognition in children before and after adenotonsillectomy. Pediatrics. 2006;117(4):e769-e778.

44. Hoban TF, Chervin RD. Assessment of sleepiness in children. Semin Pediatr Neurol. 2001;8(4):216-228.

45. Rhodes SK, Shimoda KC, Waid LR, et al. Neurocognitive deficits in morbidly obese children with obstructive sleep apnea. $J$ Pediatr. 1995;127(5):741-744.

46. Owens J, Spirito A, Marcotte A, McGuinn M, Berkelhammer L. Neuropsychological and behavioral correlates of obstructive sleep apnea syndrome in children: a preliminary study. Sleep Breath. 2000;4(2): 67-78.

47. Hansen DE, Vandenberg B. Cognitive effects of sleep apnea and narcolepsy in school age children. Sleep Hypn. 2001;3(2):73-80.

48. Kaemingk KL, Pasvogel AE, Goodwin JL, et al. Learning in children and sleep disordered breathing: findings of the Tucson Children's Assessment of Sleep Apnea (tuCASA) Prospective Cohort Study. J Int Neuropsychol Soc. 2003;9(7):1016-1026.

49. Archbold KH, Giordani B, Ruzicka DL, Chervin RD. Cognitive executive dysfunction in children with mild sleep-disordered breathing. Biol Res Nurs. 2004;5(3):168-176.

50. Kennedy JD, Blunden S, Hirte C, et al. Reduced neurocognition in children who snore. Pediatr Pulmonol. 2004;37(4):330-337.

51. O’Brien LM, Tauman R, Gozal D. Sleep pressure correlates of cognitive and behavioral morbidity in snoring children. Sleep. 2004;27(2): 279-282.

52. Halbower AC, Degaonkar M, Barker PB, et al. Childhood obstructive sleep apnea associates with neuropsychological deficits and neuronal brain injury. PLoS Med. 2006;3(8):e301.

53. Li HY, Huang YS, Chen NH, Fang TJ, Lee LA. Impact of adenotonsillectomy on behavior in children with sleep-disordered breathing. Laryngoscope. 2006;116(7):1142-1147.

54. Ziliotto KN, dos Santos MF, Monteiro VG, et al. Auditory processing assessment in children with obstructive sleep apnea syndrome. Braz J Otorhinolaryngol. 2006;72(3):321-327.

55. Gozal D, Crabtree VM, Sans Capdevila O, Witcher LA, KheirandishGozal L. C-reactive protein, obstructive sleep apnea, and cognitive dysfunction in school-aged children. Am J Respir Crit Care Med. 2007;176(2): 188-193.

56. Uema SF, Pignatari SS, Fujita R, Moreira G, Pradella-Hallinan M, Weckx LL. Assessment of cognitive learning function in children with obstructive sleep breathing disorders. Braz J Otorhinolaryngol. 2007;73(3):315-320.

57. Calhoun SL, Mayes SD, Vgontzas AN, Tsaoussoglou M, Shifflett LJ, Bixler EO. No relationship between neurocognitive functioning and mild sleep disordered breathing in a community sample of children. J Clin Sleep Med. 2009;5(3):228-234.

58. Gozal D, Sans Capdevila O, McLaughlin Crabtree V, Serpero LD, Witcher LA, Kheirandish-Gozal L. Plasma IGF-1 levels and cognitive dysfunction in children with obstructive sleep apnea. Sleep Med. 2009; 10(2):167-173.

59. Suratt PM, Peruggia M, D'Andrea L, et al. Cognitive function and behavior of children with adenotonsillar hypertrophy suspected of having obstructive sleep-disordered breathing. Pediatrics. 2006;118(3): 771-781.

60. Gottlieb DJ, Vezina RM, Chase C, et al. Symptoms of sleep-disordered breathing in 5-year-old children are associated with sleepiness and problem behaviors. Pediatrics. 2003;112(4):870-877.

61. Kohyama J, Furushima W, Hasegawa T. Behavioral problems in children evaluated for sleep disordered breathing. Sleep Hypn. 2003; 5(2):89-94.

62. Crabtree VM, Varni JW, Gozal D. Health-related quality of life and depressive symptoms in children with suspected sleep-disordered breathing. Sleep. 2004;27(6):1131-1138.

63. Mulvaney SA, Goodwin JL, Morgan WJ, Rosen GR, Quan SF, Kaemingk KL. Behavior problems associated with sleep disordered breathing in school-aged children - the Tucson Children's Assessment of Sleep Apnea Study. J Pediatr Psychol. 2006;31(3):322-330. 
64. Mitchell RB, Kelly J. Long-term changes in behavior after adenotonsillectomy for obstructive sleep apnea syndrome in children. Otolaryngol Head Neck Surg. 2006;134(3):374-378.

65. Constantin E, Kermack A, Nixon GM, Tidmarsh L, Ducharme FM, Brouillette RT. Adenotonsillectomy improves sleep, breathing, and quality of life but not behavior. J Pediatr. 2007;150(5):540-546.

66. Dillon JE, Blunden S, Ruzicka DL, et al. DSM-IV diagnoses and obstructive sleep apnea in children before and 1 year after adenotonsillectomy. J Am Acad Child Adolesc Psychiatry. 2007;46(11): $1425-1436$

67. Osler W. The Principles and Practice of Medicine. 8th ed. New York, NY: Appleton; 1919.

68. Brouillette RT, Fernbach SK, Hunt CE. Obstructive sleep apnea in infants and children. J Pediatr. 1982;100(1):31-40.

69. Ali NJ, Pitson D, Stradling JR. Natural history of snoring and related behaviour problems between the ages of 4 and 7 years. Arch Dis Child. 1994;71(1):74-76

70. Ali NJ, Pitson D, Stradling JR. Sleep disordered breathing: effects of adenotonsillectomy on behaviour and psychological functioning. Eur J Pediatr. 1996;155(1):56-62.

71. Stradling JR, Thomas G, Warley AR, Williams P, Freeland A. Effect of adenotonsillectomy on nocturnal hypoxaemia, sleep disturbance, and symptoms in snoring children. Lancet. 1990;335(8684):249-253.

72. Gozal D. Sleep-disordered breathing and school performance in children. Pediatrics. 1998;102(3 Pt 1):616-620.

73. Richards W, Ferdman RM. Prolonged morbidity due to delays in the diagnosis and treatment of obstructive sleep apnea in children. Clin Pediatr (Phila). 2000;39(2):103-108.

74. Brietzke SE, Gallagher D. The effectiveness of tonsillectomy and adenoidectomy in the treatment of pediatric obstructive sleep apnea/ hypopnea syndrome: a meta-analysis. Otolaryngol Head Neck Surg. 2006;134(6):979-984.

75. Friedman M, Wilson M, Lin HC, Chang HW. Updated systematic review of tonsillectomy and adenoidectomy for treatment of pediatric obstructive sleep apnea/hypopnea syndrome. Otolaryngol Head Neck Surg. 2009;140(6):800-808.

76. Garetz SL. Behavior, cognition, and quality of life after adenotonsillectomy for pediatric sleep-disordered breathing: summary of the literature. Otolaryngol Head Neck Surg. 2008;138(1) Suppl:S19-S26.

77. Hodges EK, Bloomfield E, Coulas T, Giordani B. Cognitive and behavioral change after adenotonsillectomy in children with sleep-disordered breathing: a review. Minerva Psichiatr. 2008;49:307-321.

78. Tran KD, Nguyen CD, Weedon J, Goldstein NA. Child behavior and quality of life in pediatric obstructive sleep apnea. Arch Otolaryngol Head Neck Surg. 2005;131(1):52-57.

79. Avior G, Fishman G, Leor A, Sivan Y, Kaysar N, Derowe A. The effect of tonsillectomy and adenoidectomy on inattention and impulsivity as measured by the Test of Variables of Attention (TOVA) in children with obstructive sleep apnea syndrome. Otolaryngol Head Neck Surg. 2004;131(4):367-371.

80. Harvey JM, O’Callaghan MJ, Wales PD, Harris MA, Masters IB. Six-month follow-up of children with obstructive sleep apnoea. J Paediatr Child Health. 1999;35(2):136-139.

81. Hogan AM, Hill CM, Harrison D, Kirkham FJ. Cerebral blood flow velocity and cognition in children before and after adenotonsillectomy. Pediatrics. 2008;122(1):75-82.

82. Moré EE, Isern FS, Zumel PH, Gonzalez AE, Soler EM, Alcover JMA. Clinical efficacy and polysomnography of adenotonsillectomy in the treatment of sleep-related respiratory disorders in children. Acta Otorrinolaringol Esp. 2008;59(7):325-333.

83. Lundeborg I, McAllister A, Samuelsson C, Ericsson E, Hultcrantz E. Phonological development in children with obstructive sleep-disordered breathing. Clin Linguist Phon. 2009;23(10):751-761.

84. Goldstein NA, Fatima M, Campbell TF, Rosenfeld RM. Child behavior and quality of life before and after tonsillectomy and adenoidectomy. Arch Otolaryngol Head Neck Surg. 2002;128(7):770-775.
85. Goldstein NA, Post JC, Rosenfeld RM, Campbell TF. Impact of tonsillectomy and adenoidectomy on child behavior. Arch Otolaryngol Head Neck Surg. 2000;126(4):494-498.

86. Roemmich JN, Barkley JE, D'Andrea L, et al. Increases in overweight after adenotonsillectomy in overweight children with obstructive sleepdisordered breathing are associated with decreases in motor activity and hyperactivity. Pediatrics. 2006;117(2):e200-e208.

87. Wei JL, Bond J, Mayo MS, Smith HJ, Reese M, Weatherly RA. Improved behavior and sleep after adenotonsillectomy in children with sleep-disordered breathing: long-term follow-up. Arch Otolaryngol Head Neck Surg. 2009;135(7):642-646.

88. Wei JL, Mayo MS, Smith HJ, Reese M, Weatherly RA. Improved behavior and sleep after adenotonsillectomy in children with sleep-disordered breathing. Arch Otolaryngol Head Neck Surg. 2007;133(10):974-979.

89. Ericsson E, Lundeborg I, Hultcrantz E. Child behavior and quality of life before and after tonsillotomy versus tonsillectomy. Int J Pediatr Otorhinolaryngol. 2009;73(9):1254-1262.

90. Lopes MC, Marcus CL. The significance of ASDA arousals in children. Sleep Med. 2007;9(1):3-8.

91. Terzano MG, Parrino L. Origin and significance of the cyclic alternating pattern (CAP). Sleep Med Rev. 2000;4(1):101-123.

92. Kheirandish-Gozal L, Miano S, Bruni O, et al. Reduced NREM sleep instability in children with sleep disordered breathing. Sleep. 2007;30(4):450-457.

93. Miano S, Paolino MC, Peraita-Adrados R, Montesano M, Barberi S, Villa MP. Prevalence of EEG paroxysmal activity in a population of children with obstructive sleep apnea syndrome. Sleep. 2009;32(4):522-529.

94. Miano S, Rizzoli A, Evangelisti M, et al. NREM sleep instability changes following rapid maxillary expansion in children with obstructive apnea sleep syndrome. Sleep Med. 2009;10(4):471-478.

95. Bruni O, Ferri R, Vittori E, et al. Sleep architecture and NREM alterations in children and adolescents with Asperger syndrome. Sleep. 2007; 30(11):1577-1585.

96. Chervin RD, Burns JW, Subotic NS, Roussi C, Thelen B, Ruzicka DL. Method for detection of respiratory cycle-related EEG changes in sleep-disordered breathing. Sleep. 2004;27(1):110-115.

97. Chervin RD, Weatherly RA, Ruzicka DL, et al. Subjective sleepiness and polysomnographic correlates in children scheduled for adenotonsillectomy vs other surgical care. Sleep. 2006;29(4):495-503.

98. Chervin RD, Burns JW, Subotic NS, Roussi C, Thelen B, Ruzicka DL. Correlates of respiratory cycle-related EEG changes in children with sleep-disordered breathing. Sleep. 2004;27(1):116-121.

99. Nowak M, Kornhuber J, Meyrer R. Daytime impairment and neurodegeneration in OSAS. Sleep. 2006;29(12):1521-1530.

100. Zimmerman ME, Aloia MS. A review of neuroimaging in obstructive sleep apnea. J Clin Sleep Med. 2006;2(4):461-471.

101. Thomas RJ, Rosen BR, Stern CE, Weiss JW, Kwong KK. Functional imaging of working memory in obstructive sleep-disordered breathing. J Appl Physiol. 2005;98(6):2226-2234.

102. Ayalon L, Ancoli-Israel S, Klemfuss Z, Shalauta MD, Drummond SP. Increased brain activation during verbal learning in obstructive sleep apnea. Neuroimage. 2006;31(4):1817-1825.

103. Fischer AQ, Chaudhary BA, Taormina MA, Akhtar B. Intracranial hemodynamics in sleep apnea. Chest. 1992;102(5):1402-1406.

104. Hajak G, Klingelhofer J, Schulz-Varszegi M, Sander D, Ruther E. Sleep apnea syndrome and cerebral hemodynamics. Chest. 1996; 110(3):670-679.

105. Lavie L. Obstructive sleep apnoea syndrome - an oxidative stress disorder. Sleep Med Rev. 2003;7(1):35-51.

106. Mills PJ, Dimsdale JE. Sleep apnea: a model for studying cytokines, sleep, and sleep disruption. Brain Behav Immun. 2004;18(4): 298-303.

107. Prabhakar NR, Kumar GK, Nanduri J, Semenza GL. ROS signaling in systemic and cellular responses to chronic intermittent hypoxia. Antioxid Redox Signal. 2007;9(9):1397-1403. 
108. El-Sheikh M, Buckhalt JA, Granger DA, Erath SA, Acebo C. The association between children's sleep disruption and salivary interleukin-6. J Sleep Res. 2007;16(2):188-197.

109. Kheirandish-Gozal L, Capdevila OS, Tauman R, Gozal D. Plasma C-reactive protein in nonobese children with obstructive sleep apnea before and after adenotonsillectomy. J Clin Sleep Med. 2006;2(3): 301-304.

110. O'Brien LM, Serpero LD, Tauman R, Gozal D. Plasma adhesion molecules in children with sleep-disordered breathing. Chest. 2006; 129(4):947-953.

111. Tauman R, Ivanenko A, O’Brien LM, Gozal D. Plasma C-reactive protein levels among children with sleep-disordered breathing. Pediatrics. 2004;113(6):e564-e569.

112. Tauman R, O'Brien LM, Gozal D. Hypoxemia and obesity modulate plasma C-reactive protein and interleukin-6 levels in sleep-disordered breathing. Sleep Breath. 2007;11(2):77-84.

113. Kaditis AG, Alexopoulos EI, Kalampouka E, et al. Morning levels of C-reactive protein in children with obstructive sleep-disordered breathing. Am J Respir Crit Care Med. 2005;171(3):282-286.

114. Montgomery-Downs HE, Krishna J, Roberts LJ II, Gozal D. Urinary $\mathrm{F}(2)$-isoprostane metabolite levels in children with sleep-disordered breathing. Sleep Breath. 2006;10(4):211-215.

115. Gozal E, Row BW, Schurr A, Gozal D. Developmental differences in cortical and hippocampal vulnerability to intermittent hypoxia in the rat. Neurosci Lett. 2001;305(3):197-201.

116. Li RC, Row BW, Kheirandish L, et al. Nitric oxide synthase and intermittent hypoxia-induced spatial learning deficits in the rat. Neurobiol Dis. 2004;17(1):44-53.

117. Xu W, Chi L, Row BW, et al. Increased oxidative stress is associated with chronic intermittent hypoxia-mediated brain cortical neuronal cell apoptosis in a mouse model of sleep apnea. Neuroscience. 2004;126(2):313-323.

118. Zhan G, Fenik P, Pratico D, Veasey SC. Inducible nitric oxide synthase in long-term intermittent hypoxia: hypersomnolence and brain injury. Am J Respir Crit Care Med. 2005;171(12):1414-1420.

119. Row BW, Liu R, Xu W, Kheirandish L, Gozal D. Intermittent hypoxia is associated with oxidative stress and spatial learning deficits in the rat. Am J Respir Crit Care Med. 2003;167(11):1548-1553.

120. Macey PM, Henderson LA, Macey KE, et al. Brain morphology associated with obstructive sleep apnea. Am J Respir Crit Care Med. 2002;166(10):1382-1387.

121. Morrell MJ, McRobbie DW, Quest RA, Cummin AR, Ghiassi R, Corfield DR. Changes in brain morphology associated with obstructive sleep apnea. Sleep Med. 2003;4(5):451-454.

122. Macey PM, Kumar R, Woo MA, Valladares EM, Yan-Go FL, Harper RM. Brain structural changes in obstructive sleep apnea. Sleep . 2008;31(7):967-977.

123. Gozal D, Capdevila OS, Kheirandish-Gozal L, Crabtree VM. APOE epsilon 4 allele, cognitive dysfunction, and obstructive sleep apnea in children. Neurology. 2007;69(3):243-249.

124. Gozal D, Capdevila OS, Kheirandish-Gozal L. Metabolic alterations and systemic inflammation in obstructive sleep apnea among nonobese and obese prepubertal children. Am J Respir Crit Care Med. 2008;177(10):1142-1149.

125. Friberg D, Sundquist J, Li X, Hemminki K, Sundquist K. Sibling risk of pediatric obstructive sleep apnea syndrome and adenotonsillar hypertrophy. Sleep. 2009;32(8):1077-1083.

126. Ovchinsky A, Rao M, Lotwin I, Goldstein NA. The familial aggregation of pediatric obstructive sleep apnea syndrome. Arch Otolaryngol Head Neck Surg. 2002;128(7):815-818.

127. Larkin EK, Patel SR, Redline S, Mignot E, Elston RC, Hallmayer J. Apolipoprotein $\mathrm{E}$ and obstructive sleep apnea: evaluating whether a candidate gene explains a linkage peak. Genet Epidemiol. 2006;30(2):101-110.

128. Kalra M, Pal P, Kaushal R, et al. Association of ApoE genetic variants with obstructive sleep apnea in children. Sleep Med. 2008;9(3):260-265.
129. Casey BJ, Tottenham N, Liston C, Durston S. Imaging the developing brain: what have we learned about cognitive development? Trends Cogn Sci. 2005;9(3):104-110.

130. White F, Hayes B, Livesay D. Developmental Psychology: From Infancy to Adulthood. Frenchs Forest, NSW, Australia: Pearson Education Australia; 2005.

131. Zelazo PD, Mueller U. Executive functions in typical and atypical development. In: Goswami U, editor. Handbook of Childhood Cognitive Development. Oxford: Blackwell; 2002:445-469.

132. Hudspeth W, Pribram K. Stages of brain and cognitive maturation. J Educ Psychol. 1990;82:881-884.

133. Kriel R, Krach L, Panser L. Closed head injury: comparison of children younger and older than six years of age. Pediatr Neurol. 1989;5:296-300.

134. Anderson V, Catroppa C. Recovery of executive skills following paediatric traumatic brain injury (TBI): a 2 year follow-up. Brain Inj. 2005;19(6):459-470

135. Chugani HT. A critical period of brain development: studies of cerebral glucose utilization with PET. Prev Med. 1998;27(2):184-188.

136. Shaw $P$, Greenstein D, Lerch J, et al. Intellectual ability and cortical development in children and adolescents. Nature. 2006;440(7084): 676-679.

137. Mahone EM, Hagelthorn KM, Cutting LE, et al. Effects of IQ on executive function measures in children with ADHD. Child Neuropsychol. 2002;8(1):52-65.

138. Alchanatis M, Zias N, Deligiorgis N, Amfilochiou A, Dionellis G, Orphanidou D. Sleep apnea-related cognitive deficits and intelligence: an implication of cognitive reserve theory. J Sleep Res. 2005; 14(1):69-75.

139. Guilleminault C, Korobkin R, Winkle R. A review of 50 children with obstructive sleep apnea syndrome. Lung. 1981;159(5):275-287.

140. Weissbluth M, Davis AT, Poncher J, Reiff J. Signs of airway obstruction during sleep and behavioral, developmental, and academic problems. J Dev Behav Pediatr. 1983;4(2):119-121.

141. Brouilette R, Hanson D, David R, et al. A diagnostic approach to suspected obstructive sleep apnea in children. J Pediatr. 1984; 105(1):10-14.

142. Ali NJ, Pitson DJ, Stradling JR. Snoring, sleep disturbance, and behaviour in 4-5 year olds. Arch Dis Child. 1993;68(3):360-366.

143. Carskadon MA, Pueschel SM, Millman RP. Sleep-disordered breathing and behavior in three risk groups: preliminary findings from parental reports. Childs Nerv Syst. 1993;9:452-457.

144. Guilleminault C, Pelayo R, Leger D, Clerk A, Bocian RC. Recognition of sleep-disordered breathing in children. Pediatrics. 1996;98(5):871-882.

145. Chervin RD, Dillon JE, Bassetti C, Ganoczy DA, Pituch KJ. Symptoms of sleep disorders, inattention, and hyperactivity in children. Sleep. 1997;20(12):1185-1192.

146. Owens-Stively J, Frank N, Smith A, et al. Child temperament, parenting discipline style, and daytime behavior in childhood sleep disorders. $J$ Dev Behav Pediatr. 1997;18(5):314-321.

147. Owens J, Opipari L, Nobile C, Spirito A. Sleep and daytime behavior in children with obstructive sleep apnea and behavioral sleep disorders. Pediatrics. 1998;102(5):1178-1184.

148. Ferreira AM, Clemente V, Gozal D, et al. Snoring in Portuguese primary school children. Pediatrics. 2000;106(5):E64

149. Kelmanson IA. Snoring, noisy breathing in sleep and daytime behaviour in 2-4-month-old infants. Eur J Pediatr. 2000;159(10):734-739.

150. Brunetti L, Rana S, Lospalluti ML, et al. Prevalence of obstructive sleep apnea syndrome in a cohort of 1,207 children of southern Italy. Chest. 2001;120(6):1930-1935.

151. Chervin RD, Archbold KH. Hyperactivity and polysomnographic findings in children evaluated for sleep-disordered breathing. Sleep. 2001;24(3):313-320.

152. Gozal D, Pope DW Jr. Snoring during early childhood and academic performance at ages thirteen to fourteen years. Pediatrics. 2001; 107(6):1394-1399. 
153. Smedje H, Broman JE, Hetta J. Associations between disturbed sleep and behavioural difficulties in 635 children aged six to eight years: a study based on parents' perceptions. Eur Child Adolesc Psychiatry. 2001;10(1):1-9.

154. Stein MA, Mendelsohn J, Obermeyer WH, Amromin J, Benca R. Sleep and behavior problems in school-aged children. Pediatrics. 2001;107(4):E60.

155. Chervin RD, Archbold KH, Dillon JE, et al. Inattention, hyperactivity, and symptoms of sleep-disordered breathing. Pediatrics. 2002;109(3):449-456.

156. Castronovo V, Zucconi M, Nosetti L, et al. Prevalence of habitual snoring and sleep-disordered breathing in preschool-aged children in an Italian community. $J$ Pediatr. 2003;142(4):377-382.

157. Chervin RD, Dillon JE, Archbold KH, Ruzicka DL. Conduct problems and symptoms of sleep disorders in children. J Am Acad Child Adolesc Psychiatry. 2003;42(2):201-208.

158. Shin C, Joo S, Kim J, Kim T. Prevalence and correlates of habitual snoring in high school students. Chest. 2003;124(5):1709-1715

159. Urschitz MS, Eitner S, Guenther A, et al. Habitual snoring, intermittent hypoxia, and impaired behavior in primary school children. Pediatrics. 2004;114(4):1041-1048.

160. Urschitz MS, Guenther A, Eggebrecht E, et al. Snoring, intermittent hypoxia and academic performance in primary school children. Am J Respir Crit Care Med. 2003;168(4):464-468.

161. Ersu R, Arman AR, Save D, et al. Prevalence of snoring and symptoms of sleep-disordered breathing in primary school children in Istanbul. Chest. 2004;126(1):19-24.

162. Huang YS, Chen NH, Li HY, Wu YY, Chao CC, Guilleminault C. Sleep disorders in Taiwanese children with attention deficit/ hyperactivity disorder. J Sleep Res. 2004;13(3):269-277.

163. Kaditis AG, Finder J, Alexopoulos EI, et al. Sleep-disordered breathing in 3,680 Greek children. Pediatr Pulmonol. 2004;37(6): 499-509.

164. Rosen CL, Storfer-Isser A, Taylor HG, Kirchner HL, Emancipator JL, Redline S. Increased behavioral morbidity in school-aged children with sleep-disordered breathing. Pediatrics. 2004;114(6): 1640-1648.

165. Arman AR, Ersu R, Save D, et al. Symptoms of inattention and hyperactivity in children with habitual snoring: evidence from a community-based study in Istanbul. Child Care Health Dev. 2005;31(6): 707-717.
166. Blunden S, Lushington K, Lorenzen B, Martin J, Kennedy D. Neuropsychological and psychosocial function in children with a history of snoring or behavioral sleep problems. J Pediatr. 2005;146(6): 780-786.

167. Carvalho LB, Prado LF, Silva L, et al. Cognitive dysfunction in children with sleep-disordered breathing. J Child Neurol. 2005;20(5): 400-404.

168. Chervin RD. How many children with ADHD have sleep apnea or periodic leg movements on polysomnography? Sleep. 2005; 28(9):1041-1042.

169. Goodwin JL, Kaemingk KL, Mulvaney SA, Morgan WJ, Quan SF. Clinical screening of school children for polysomnography to detect sleep-disordered breathing - the Tucson Children's Assessment of Sleep Apnea Study (TuCASA). J Clin Sleep Med. 2005;1(3):247-254.

170. Sogut A, Altin R, Uzun L, et al. Prevalence of obstructive sleep apnea syndrome and associated symptoms in 3-11-year-old Turkish children. Pediatr Pulmonol. 2005;39(3):251-256.

171. Urschitz MS, Wolff J, Sokollik C, et al. Nocturnal arterial oxygen saturation and academic performance in a community sample of children. Pediatrics. 2005;115(2):e204-e209.

172. Emancipator JL, Storfer-Isser A, Taylor HG, et al. Variation of cognition and achievement with sleep-disordered breathing in full-term and preterm children. Arch Pediatr Adolesc Med. 2006;160(2):203-210.

173. Hiscock H, Canterford L, Ukoumunne OC, Wake M. Adverse associations of sleep problems in Australian preschoolers: national population study. Pediatrics. 2007;119(1):86-93.

174. Karpinski AC, Scullin MH, Montgomery-Downs HE. Risk for sleep-disordered breathing and executive function in preschoolers. Sleep Med. 2008;9(4):418-424.

175. Aronen ET, Liukkonen K, Simola P, et al. Mood is associated with snoring in preschool-aged children. J Dev Behav Pediatr. 2009;30(2): 107-114.

176. Harvey JM, O’Callaghan MJ, Wales PD, Harris MA, Masters IB. Aetiological factors and development in subjects with obstructive sleep apnoea. J Paediatr Child Health. 1999;35(2):140-144. 


\section{Appendix}

Appendix A Summary of published studies investigating neurocognitive performance and behavior in children with SDB

\begin{tabular}{|c|c|c|c|c|c|}
\hline Authors & Population & $\begin{array}{l}\text { SDB/snoring } \\
\text { measure }\end{array}$ & $\begin{array}{l}\text { Neurocognitive } \\
\text { dysfunction }\end{array}$ & $\begin{array}{l}\text { Behavioral } \\
\text { dysfunction }\end{array}$ & Note \\
\hline Guilleminault et $\mathrm{al}^{6}$ & 8 OSAS (5-14 y) & PSG & Academic difficulties & $\begin{array}{l}\text { Emotional disturbance, } \\
\text { hyperactive, sleepiness }\end{array}$ & $\begin{array}{l}\text { Anecdotal } \\
\text { reports only }\end{array}$ \\
\hline Guilleminault et al ${ }^{139}$ & $\begin{array}{l}24 \text { OSAS, } 26 \text { OSAS } \\
\text { secondary to medical } \\
\text { problem, } 22 \text { controls } \\
\text { (all I-16 y) }\end{array}$ & $\begin{array}{l}\text { Esophageal } \\
\text { pressure, PSG }\end{array}$ & $\begin{array}{l}\text { Academic difficulties, } \\
\text { language }\end{array}$ & $\begin{array}{l}\text { Aggression, hyperactive, } \\
\text { inattentive, sleepiness, } \\
\text { withdrawn }\end{array}$ & $\begin{array}{l}\text { Anecdotal } \\
\text { reports only }\end{array}$ \\
\hline Brouillette et $\mathrm{a}^{68}$ & 22 OSAS $(3-5 y)$ & Daytime PSG & Not reported & $\begin{array}{l}\text { General behavior, } \\
\text { sleepiness }\end{array}$ & $\begin{array}{l}\text { Anecdotal } \\
\text { reports and } \\
\text { unspecified } \\
\text { measures }\end{array}$ \\
\hline Guilleminault et $\mathrm{al}^{7}$ & $\begin{array}{l}25 \text { snorers, } 25 \text { controls } \\
\text { (all } 2-14 \text { y) }\end{array}$ & $\begin{array}{l}\text { Esophageal } \\
\text { pressure, PSG }\end{array}$ & Academic difficulties & $\begin{array}{l}\text { Aggressive, hyperactive, } \\
\text { sleepiness, withdrawn }\end{array}$ & $\begin{array}{l}\text { Anecdotal } \\
\text { reports only }\end{array}$ \\
\hline Weissbluth et al ${ }^{140}$ & $\begin{array}{l}71 \text { behavior, academic, } \\
\text { an development problems } \\
(6.2 \pm 3.5 \text { y); } 355 \text { controls } \\
(5.8 \pm 3.1 \text { y) }\end{array}$ & Questionnaire & Academic difficulties & Hyperactive, inattentive & $\begin{array}{l}\text { No PSG, } \\
\text { nonvalidated } \\
\text { behavior measure }\end{array}$ \\
\hline Brouillette et al ${ }^{\mid 41}$ & $\begin{array}{l}23 \text { OSAS }(3.8 \pm 2.4 y) \\
46 \text { controls }(4.0 \pm 2.3 y)\end{array}$ & PSG, questionnaire & NA & Sleepiness, withdrawn & $\begin{array}{l}\text { PSG in OSAS } \\
\text { group only, } \\
\text { nonvalidated } \\
\text { behavior measure }\end{array}$ \\
\hline Stradling et $\mathrm{a}^{\mathrm{P}^{71}}$ & $\begin{array}{l}61 \text { snorers }(4.7 \pm 1.7 y) \\
31 \text { controls }(4.7 \pm 1.7 y)\end{array}$ & $\begin{array}{l}\text { Home oximetry and } \\
\text { video, questionnaire }\end{array}$ & NA & Aggressive, hyperactive & $\begin{array}{l}\text { Nonvalidated } \\
\text { behavior measure }\end{array}$ \\
\hline Ali et al ${ }^{142}$ & $\begin{array}{l}782 \text { from health registrar - } \\
66 \text { SDB, } 66 \text { controls } \\
\text { (all aged } 4-5 \text { y) }\end{array}$ & $\begin{array}{l}\text { Home oximetry and } \\
\text { video, questionnaire }\end{array}$ & NA & $\begin{array}{l}\text { Aggressive, hyperactive, } \\
\text { inattentive }\end{array}$ & $\begin{array}{l}\text { Nonvalidated } \\
\text { behavior measure }\end{array}$ \\
\hline Carskadon et al $\left.\right|^{143}$ & $\begin{array}{l}29 \text { children with } \\
\text { adenotonsillar } \\
\text { hypertrophy }(8.7 \pm 3.0 \mathrm{y})\end{array}$ & Questionnaire & NA & Disruptive & $\begin{array}{l}\text { Nonvalidated } \\
\text { behavior measure, } \\
\text { no control group }\end{array}$ \\
\hline Ali et al ${ }^{69}$ & $\begin{array}{l}507 \text { from health registrar } \\
\text { (all aged } 6.5-7.5 \text { y) - } \\
56 \text { snorers }\end{array}$ & Questionnaire & NA & Hyperactive, sleepiness & \\
\hline Rhodes et $\mathrm{al}^{45}$ & $\begin{array}{l}5 \text { patients with OSAS } \\
(I 2.9 \pm 2.1 \text { y }), 9 \text { clinical } \\
\text { patients with no OSAS } \\
(I 3.5 \pm I .5 y)\end{array}$ & PSG & Learning, memory & NA & $\begin{array}{l}\text { All subjects were } \\
\text { obese }\end{array}$ \\
\hline Ali et $\mathrm{al}^{70}$ & $\begin{array}{l}12 \operatorname{SDB}(5-12 y), \\
11 \text { snorers }(6-12 y) \text {, } \\
10 \text { controls }(6-12 y)\end{array}$ & $\begin{array}{l}\text { Questionnaire, } \\
\text { home nocturnal } \\
\text { oximetry and video }\end{array}$ & $\begin{array}{l}\text { No between-group } \\
\text { differences (IQ, } \\
\text { attention, } \\
\text { response speed) }\end{array}$ & $\begin{array}{l}\text { Aggressive, hyperactive, } \\
\text { inattentive }\end{array}$ & \\
\hline Guilleminault et al ${ }^{144}$ & $\begin{array}{l}4 I I \text { sleep clinic patients } \\
\text { (birth to } 12 \mathrm{y} \text { ) }\end{array}$ & $\begin{array}{l}\text { Esophageal } \\
\text { pressure, PSG }\end{array}$ & NA & Oppositional & $\begin{array}{l}\text { Nonvalidated } \\
\text { behavior measure }\end{array}$ \\
\hline Chervin et al ${ }^{145}$ & $\begin{array}{l}27 \text { ADHD patients } \\
(9.5 \pm 3.7 \mathrm{y}) \\
\text { II } 6 \text { non-ADHD } \\
\text { patients }(8.9 \pm 4.7 \mathrm{y})\end{array}$ & Questionnaire & NA & Hyperactive, inattention & $\begin{array}{l}\text { Groups defined by } \\
\text { ADHD symptom, } \\
\text { nonvalidated } \\
\text { behavior measure }\end{array}$ \\
\hline Owens-Stively et al ${ }^{146}$ & $\begin{array}{l}23 \text { OSAS (age not } \\
\text { reported) }\end{array}$ & PSG & Attention & $\begin{array}{l}\text { Impulsivity and } \\
\text { inattentiveness compared } \\
\text { with moderate/severe } \\
\text { OSA, mild OSA more } \\
\text { severe hyperactivity }\end{array}$ & No control group \\
\hline Gozal $^{72}$ & $\begin{array}{l}297 \text { first grade children } \\
\text { with poor academic } \\
\text { performance ( } 177 \text { controls, } \\
66 \text { primary snorers, } \\
30 \text { nontreated SDB, and } \\
24 \text { treated SDB) }\end{array}$ & $\begin{array}{l}\text { Home oximetry } \\
\text { and } \mathrm{TcCO}_{2} \text {, } \\
\text { questionnaire }\end{array}$ & $\begin{array}{l}\text { Academic } \\
\text { performance }\end{array}$ & NA & \\
\hline
\end{tabular}


Appendix A (Continued)

\begin{tabular}{|c|c|c|c|c|c|}
\hline Authors & Population & $\begin{array}{l}\text { SDB/snoring } \\
\text { measure }\end{array}$ & $\begin{array}{l}\text { Neurocognitive } \\
\text { dysfunction }\end{array}$ & $\begin{array}{l}\text { Behavioral } \\
\text { dysfunction }\end{array}$ & Note \\
\hline Owens et al ${ }^{147}$ & $\begin{array}{l}\text { I00 OSAS }(8.9 \pm 4.7 \text { y) } \\
\text { vs } 52 \text { behavioral sleep } \\
\text { problems }\end{array}$ & PSG & NA & $\begin{array}{l}\text { OSAS patients } \\
\text { displayed less problematic } \\
\text { behavior compared with } \\
\text { children with behavioral } \\
\text { sleep problems }\end{array}$ & $\begin{array}{l}\text { Snoring evident } \\
\text { in the group with } \\
\text { behavioral sleep } \\
\text { problems }\end{array}$ \\
\hline Harvey et a $\left.\right|^{80}$ & $56 \operatorname{SDB}(2.9 \pm 1.3 y)$ & PSG & Not reported & Not reported & $\begin{array}{l}28 \% \\
\text { neurologically } \\
\text { abnormal }\end{array}$ \\
\hline Blunden et $\mathrm{al}^{31}$ & $\begin{array}{l}16 \text { snorers }(7.2,5-10 y) \\
16 \text { controls }(7.7,5-10 y)\end{array}$ & $\begin{array}{l}\text { PSG }(n=26) \text {, } \\
\text { questionnaire }\end{array}$ & $\begin{array}{l}\text { Attention, IQ, } \\
\text { memory }\end{array}$ & $\begin{array}{l}\text { No differences } \\
\text { between groups }\end{array}$ & $\begin{array}{l}\text { Groups not } \\
\text { matched for SES }\end{array}$ \\
\hline Ferreira et al ${ }^{148}$ & $\begin{array}{l}976 \text { children }(8.1 \pm I .5 \text { y) } \\
\text { from community } \\
(8.8 \% \text { habitual snorers })\end{array}$ & Questionnaire & NA & Irritability, sleepiness & \\
\hline Goldstein et al ${ }^{85}$ & 36 snorers $(4.6,2-10 y)$ & $\begin{array}{l}\text { Questionnaire, } \\
\text { physical examination }\end{array}$ & NA & Externalizing & No control group \\
\hline Kelmanson ${ }^{149}$ & $\begin{array}{l}200 \text { infants }-7 \mathrm{I} \text { snorers/ } \\
\text { noisy breathing }(3.0 \pm \\
1.0 \mathrm{mo})\end{array}$ & Questionnaire & NA & Negative mood & $\begin{array}{l}\text { Nonvalidated } \\
\text { sleep measure }\end{array}$ \\
\hline Owens et $\mathrm{al}^{146}$ & I8 OSAS $(7.3 \pm 2.0 y)$ & PSG & $\begin{array}{l}\text { No difference } \\
\text { between mild and } \\
\text { moderate OSAS }\end{array}$ & $\begin{array}{l}\text { Learning problems, } \\
\text { somatic complaints, } \\
\text { no difference between } \\
\text { mild and moderate OSAS }\end{array}$ & No control group \\
\hline $\begin{array}{l}\text { Richards and } \\
\text { Ferdman }{ }^{73}\end{array}$ & $\begin{array}{l}45 \text { OSAS post-AT } \\
(2.5-15.5 \mathrm{y})\end{array}$ & PSG, questionnaire & School performance & Sleepiness & $\begin{array}{l}\text { Retrospective } \\
\text { review, no } \\
\text { control group }\end{array}$ \\
\hline Brunetti et al ${ }^{150}$ & $\begin{array}{l}895 \text { school students } \\
(7.3 \text { y, 3-II y) - } 44 \text { habitual } \\
\text { snorers }(4.9 \%)\end{array}$ & $\begin{array}{l}\text { Questionnaire, limited } \\
\text { home PSG }(n=34) \text {, } \\
\text { laboratory PSG } \\
(n=12)\end{array}$ & $\begin{array}{l}\text { Academic } \\
\text { performance }\end{array}$ & Hyperactive & \\
\hline $\begin{array}{l}\text { Chervin and } \\
\text { Archbold }{ }^{151}\end{array}$ & $\begin{array}{l}\text { II } 3 \text { sleep clinical patients } \\
(9.9 \pm 4.0 \text { y })-59 \text { SDB, } \\
54 \text { non-SDB }\end{array}$ & PSG & NA & $\begin{array}{l}\text { No reported } \\
\text { associations }\end{array}$ & $\begin{array}{l}\text { Non-SDB group } \\
\text { included primary } \\
\text { snorers }\end{array}$ \\
\hline Gozal and Pope ${ }^{152}$ & $\begin{array}{l}797 \text { low-performing } \\
\text { students, } 791 \text { high- } \\
\text { performing students } \\
\text { (all I3-14 y) }\end{array}$ & Questionnaire & $\begin{array}{l}\text { Snoring more likely } \\
\text { amongst low- } \\
\text { performing } \\
\text { students }\end{array}$ & NA & \\
\hline $\begin{array}{l}\text { Hansen and } \\
\text { Vandenberg }\end{array}$ & $\begin{array}{l}7 \text { OSAS }(7.3 \pm 2.0 y) \\
7 \text { narcoleptics }(7.3 \pm 2.0 y)\end{array}$ & PSG & Attention & NA & No control group \\
\hline Smedje et al $\left.\right|^{153}$ & $\begin{array}{l}635 \text { children }(84 \pm 5 \mathrm{mo}) \\
\text { from community } \\
(9.3 \% \text { habitual snorers })\end{array}$ & Questionnaire & NA & $\begin{array}{l}\text { No reported } \\
\text { associations }\end{array}$ & \\
\hline Stein et al ${ }^{154}$ & $\begin{array}{l}472 \text { children }(4-12 \text { y) } \\
\text { from pediatric clinic } \\
(23 \% \text { snored }>I \text { night } / \mathrm{wk})\end{array}$ & Questionnaire & NA & $\begin{array}{l}\text { Social problems, } \\
\text { somatic complaints }\end{array}$ & \\
\hline $\begin{array}{l}\text { Chervin and } \\
\text { Archbold }{ }^{151}\end{array}$ & $\begin{array}{l}866 \text { children attending } \\
\text { clinics }(6.8 \pm 3.2 \text { y), } \\
\text { I } 39 \text { habitual snorers }\end{array}$ & Questionnaire & NA & $\begin{array}{l}\text { Snoring associated } \\
\text { with hyperactivity }\end{array}$ & \\
\hline Goldstein et $\mathrm{a}^{184}$ & $\begin{array}{l}64 \text { children awaiting } \\
\text { AT }(7.3 \pm 2.0 y)\end{array}$ & $\begin{array}{l}\text { Questionnaire, } \\
\text { physical examination }\end{array}$ & NA & $\begin{array}{l}\text { All behaviors within } \\
\text { clinical range }\end{array}$ & No control group \\
\hline Lewin et al ${ }^{19}$ & $\begin{array}{l}12 \text { severe OSAS } \\
(6.6 \pm 1.5 \mathrm{y}), 16 \text { mild } \\
\text { OSAS }(7.6 \pm 3.0 \mathrm{y}) \\
10 \text { controls }(6.9 \pm 1.1 \mathrm{y})\end{array}$ & $\begin{array}{l}\text { PSG (OSAS only), } \\
\text { questionnaire }\end{array}$ & $\begin{array}{l}\text { Information processing, } \\
\text { verbal IQ (associations } \\
\text { and group differences } \\
\text { reported for severe } \\
\text { OSAS group and } \\
\text { controls only) }\end{array}$ & $\begin{array}{l}\text { Internalizing problems, } \\
\text { somatic complaints, } \\
\text { externalizing problems, } \\
\text { anxiety/depression, } \\
\text { social problems in mild } \\
\text { OSAS group only }\end{array}$ & $\begin{array}{l}\text { No PSG in } \\
\text { control group }\end{array}$ \\
\hline
\end{tabular}


Appendix A (Continued)

\begin{tabular}{|c|c|c|c|c|c|}
\hline Authors & Population & $\begin{array}{l}\text { SDB/snoring } \\
\text { measure }\end{array}$ & $\begin{array}{l}\text { Neurocognitive } \\
\text { dysfunction }\end{array}$ & $\begin{array}{l}\text { Behavioral } \\
\text { dysfunction }\end{array}$ & Note \\
\hline Castronovo et al ${ }^{156}$ & $\begin{array}{l}447 \text { children }(4.1 \pm \\
0.9 \text { y) from community, } \\
\text { I54 habitual snorers }\end{array}$ & $\begin{array}{l}\text { Questionnaire, } \\
\text { limited home PSG } \\
(n=24 I)\end{array}$ & NA & Irritable & $\begin{array}{l}\text { Nonvalidated } \\
\text { behavior measure }\end{array}$ \\
\hline Chervin et $\mathrm{al}^{22}$ & $\begin{array}{l}\text { I46 school children } \\
(9.3 \pm 0.4 y)\end{array}$ & Questionnaire & $\begin{array}{l}\text { Teacher reports of } \\
\text { performance but not } \\
\text { objective test scores }\end{array}$ & NA & \\
\hline Chervin et $\mathrm{al}^{157}$ & $\begin{array}{l}872 \text { children attending } \\
\text { clinics }(6.7 \pm 3.2 y)\end{array}$ & Questionnaire & NA & $\begin{array}{l}\text { Aggression, } \\
\text { conduct problems }\end{array}$ & \\
\hline Freidman et $\mathrm{al}^{16}$ & $\begin{array}{l}39 \text { OSAS }(6.8 \pm 0.2 y) \\
20 \text { controls }(7.4 \pm 1.4 y)\end{array}$ & $\begin{array}{l}\text { PSG (OSAS only), } \\
\text { questionnaire }\end{array}$ & $\begin{array}{l}\text { Analytic thinking, } \\
\text { auditory-visual } \\
\text { integration, general } \\
\text { intelligence, memory }\end{array}$ & NA & $\begin{array}{l}\text { No PSG in } \\
\text { control group }\end{array}$ \\
\hline Gottlieb et $\mathrm{al}^{60}$ & $\begin{array}{l}3,019 \text { children (all } 5 \text { y, } \\
362 \text { habitual snorers) }\end{array}$ & Questionnaire & NA & $\begin{array}{l}\text { Aggression, hyperactive, } \\
\text { inattentive, sleepiness }\end{array}$ & \\
\hline Kaemingk et $\mathrm{al}^{48}$ & $\begin{array}{l}\text { I49 school children } \\
(8.4 \pm \mathrm{I} .7 \mathrm{y}), 77 \mathrm{AHI} \geq 5\end{array}$ & PSG & Memory & None found & \\
\hline Kohyama et $a^{61}$ & $\begin{array}{l}32 \operatorname{SDB}(5.6,4-9 y) \\
137 \text { controls }(5.3,4-6 y)\end{array}$ & PSG (SDB only) & NA & $\begin{array}{l}\text { Anxiety, inattention, } \\
\text { social problems, } \\
\text { somatic complaints, } \\
\text { thought problems, } \\
\text { withdrawn }\end{array}$ & $\begin{array}{l}\text { No sleep } \\
\text { assessment for } \\
\text { controls }\end{array}$ \\
\hline $\begin{array}{l}\text { Montgomery- } \\
\text { Downs et } \mathrm{al}^{23}\end{array}$ & $\begin{array}{l}746 \text { developmentally or } \\
\text { financially disadvantaged } \\
\text { children }(4.2 \pm 0.53 \mathrm{y})\end{array}$ & Questionnaire & School performance & $\begin{array}{l}\text { Hyperactivity, } \\
\text { sleepiness }\end{array}$ & $\begin{array}{l}\text { High percentage } \\
\text { on nonresponders }\end{array}$ \\
\hline O'Brien et $\mathrm{al}^{13}$ & $\begin{array}{l}\text { 7I children with ADHD } \\
\text { symptoms, } 39 \text { controls } \\
\text { (all 5-7 y) }\end{array}$ & PSG, questionnaire & No reported effects & $\begin{array}{l}\text { OSAS and snoring are } \\
\text { more prevalent when } \\
\text { ADHD symptoms } \\
\text { are mild }\end{array}$ & $\begin{array}{l}\text { Groups defined } \\
\text { by ADHD } \\
\text { symptoms, } \\
\text { limited analysis of } \\
\text { contribution of } \\
\text { OSAS }\end{array}$ \\
\hline Shin et $\mathrm{al}^{158}$ & $\begin{array}{l}3,87 \text { I high-school } \\
\text { students ( } 16.8 \text { y), } \\
433 \text { habitual snorers }\end{array}$ & Questionnaire & School grades & Sleepiness & $\begin{array}{l}\text { Nonvalidated } \\
\text { sleep and } \\
\text { behavior measure }\end{array}$ \\
\hline Urschitz et al 159, 160 & $\begin{array}{l}\text { I, I } 44 \text { school children } \\
(9.6 \pm 0.7 y) \\
\text { I } 14 \text { habitual snorers }\end{array}$ & $\begin{array}{l}\text { Questionnaire, } \\
\text { home nocturnal } \\
\text { oximetry }\end{array}$ & $\begin{array}{l}\text { Mathematical, } \\
\text { science, and spelling } \\
\text { performance }\end{array}$ & $\begin{array}{l}\text { Attention, hyperactive, } \\
\text { sleepiness }\end{array}$ & \\
\hline Archbold et $\mathrm{al}^{49}$ & $\begin{array}{l}12 \text { children scheduled } \\
\text { for AT }(9.0 \pm 0.85 y)\end{array}$ & PSG & $\begin{array}{l}\text { Sustained attention, } \\
\text { vigilance }\end{array}$ & NA & No control group \\
\hline Avior et $\mathrm{al}^{79}$ & $\begin{array}{l}19 \text { OSAS }(8.0 y, \\
\text { range } 5-14 y)\end{array}$ & $\begin{array}{l}\text { Questionnaire, } \\
\text { adenotonsillar } \\
\text { hypertrophy }\end{array}$ & Attention & Attention & No control group \\
\hline Beebe et $\mathrm{al}^{24}$ & $\begin{array}{l}32 \operatorname{SDB}(6.7 \pm 0.5 y) \\
17 \text { controls }(6.7 \pm 0.5 y)\end{array}$ & $\begin{array}{l}\text { PSG (SDB only), } \\
\text { questionnaire }\end{array}$ & Verbal fluency & $\begin{array}{l}\text { Aggression, } \\
\text { conduct problems, } \\
\text { hyperactive }\end{array}$ & $\begin{array}{l}\text { Psychostimulants } \\
\text { use amongst } \\
\text { controls, no PSG } \\
\text { for control }\end{array}$ \\
\hline Crabtree et $a^{62}$ & $\begin{array}{l}85 \operatorname{SDB}(10.1 \pm 1.5 \mathrm{y}) \\
35 \text { controls }(9.6 \pm 0.9 \mathrm{y})\end{array}$ & PSG, questionnaire & NA & $\begin{array}{l}\text { Depression, social } \\
\text { problems }\end{array}$ & \\
\hline Ersu et $\mathrm{al}^{161}$ & $\begin{array}{l}2,147 \text { school students } \\
(8.5 \pm I .3 \mathrm{y}), \mathrm{I} \mid \mathrm{I} \text { habitual } \\
\text { snorers }\end{array}$ & Questionnaire & NA & $\begin{array}{l}\text { Hyperactive, } \\
\text { sleepiness }\end{array}$ & \\
\hline Gottlieb et $\mathrm{al}^{17}$ & $\begin{array}{l}\text { 6I SDB, } 144 \text { controls } \\
\text { (all } 5 \mathrm{y} \text { ) }\end{array}$ & $\begin{array}{l}\text { Questionnaire, } \\
\text { PSG }(n=180)\end{array}$ & $\begin{array}{l}\text { Attention, executive } \\
\text { function, hand-eye } \\
\text { coordination, IQ, } \\
\text { memory }\end{array}$ & $\begin{array}{l}\text { ADHD symptoms, } \\
\text { inattention }\end{array}$ & \\
\hline
\end{tabular}


Appendix A (Continued)

\begin{tabular}{|c|c|c|c|c|c|}
\hline Authors & Population & $\begin{array}{l}\text { SDB/snoring } \\
\text { measure }\end{array}$ & $\begin{array}{l}\text { Neurocognitive } \\
\text { dysfunction }\end{array}$ & $\begin{array}{l}\text { Behavioral } \\
\text { dysfunction }\end{array}$ & Note \\
\hline Huang et al $^{162}$ & $\begin{array}{l}88 \text { ADHD }(8.5 \pm 1.9 y, \\
50 \text { with OSA), } \\
27 \text { controls }(9.0 \pm 2.0 y)\end{array}$ & PSG, questionnaire & Response time & Hyperactive & \\
\hline Kaditis et $\mathrm{al}^{163}$ & $\begin{array}{l}3,680 \text { school students } \\
\text { ( } 1-18 \mathrm{y} \text {, median age } 9.8 \mathrm{y}) \text {, } \\
\text { I54 habitual snorers }\end{array}$ & $\begin{array}{l}\text { PSG }(n=70) \text {, } \\
\text { questionnaire }\end{array}$ & NA & Sleepiness & \\
\hline Kennedy et $\mathrm{al}^{50}$ & $\begin{array}{l}\text { I3 snorers }(7.0 \pm 4.0 y) \\
\text { I3 controls }(7.0 \pm 4.0 y)\end{array}$ & PSG & $\begin{array}{l}\text { Attention, IQ, } \\
\text { memory, verbal }\end{array}$ & NA & \\
\hline Melendres et $\mathrm{al}^{4 \mathrm{I}}$ & $\begin{array}{l}\text { I08 SDB }(7.0 \pm 4.0 y) \\
72 \text { controls }(8.0 \pm 4.0 y)\end{array}$ & $\begin{array}{l}\text { PSG (SDB only), } \\
\text { questionnaire }\end{array}$ & NA & $\begin{array}{l}\text { Hyperactive, } \\
\text { sleepiness }\end{array}$ & \\
\hline O'Brien et $\mathrm{al}^{27}$ & $\begin{array}{l}35 \operatorname{SDB}(6.7 \pm 0.6 y) \\
35 \text { controls }(6.7 \pm 0.5 y)\end{array}$ & PSG, questionnaire & $\begin{array}{l}\text { Executive function, } \\
\text { phonological } \\
\text { processing, visual } \\
\text { attention }\end{array}$ & $\begin{array}{l}\text { No differences } \\
\text { between groups }\end{array}$ & $\begin{array}{l}\text { Testing on } \\
\text { morning after } \\
\text { PSG }\end{array}$ \\
\hline O’Brien et $\mathrm{al}^{51}$ & $\begin{array}{l}49 \text { high sleep pressure } \\
\text { score (SPS) }(6.7 \pm 0.5 \mathrm{y}) \\
\text { I } 50 \text { low SPS }(6.7 \pm 0.5 \mathrm{y})\end{array}$ & PSG, questionnaire & $\begin{array}{l}\text { Language, verbal IQ, } \\
\text { visuospatial, memory }\end{array}$ & Inattention & $\begin{array}{l}\text { Low SPS also } \\
\text { displayed } \\
\text { significant } \\
\text { obstruction }\end{array}$ \\
\hline O'Brien et $\mathrm{al}^{26}$ & $\begin{array}{l}87 \text { snorers }(6.6 \pm 0.5 y) \\
31 \text { controls }(6.8 \pm 0.4 y)\end{array}$ & PSG, questionnaire & $\begin{array}{l}\text { Language, visual } \\
\text { attention, visuospatial }\end{array}$ & $\begin{array}{l}\text { Anxiety, delinquency, } \\
\text { depression, hyperactive, } \\
\text { inattention, social } \\
\text { problems, withdrawn }\end{array}$ & \\
\hline Rosen et al ${ }^{164}$ & $\begin{array}{l}162 \operatorname{SDB}(9.5 \pm 0.9 y) \\
667 \text { controls }(9.5 \pm 0.8 y)\end{array}$ & $\begin{array}{l}\text { Limited PSG, } \\
\text { questionnaire }\end{array}$ & NA & $\begin{array}{l}\text { Aggressive, emotionally } \\
\text { labile, hyperactive, } \\
\text { oppositional, social } \\
\text { problems, somatic } \\
\text { complaints }\end{array}$ & $\begin{array}{l}\text { Inclusion in SDB } \\
\text { group could be } \\
\text { based on parental } \\
\text { report only }\end{array}$ \\
\hline Arman et $\mathrm{al}^{165}$ & $\begin{array}{l}96 \text { habitual snorers } \\
(9.3 \pm 1.4 \mathrm{y}) \\
190 \text { controls }(9.4 \pm 1.2 \mathrm{y})\end{array}$ & Questionnaire & NA & $\begin{array}{l}\text { ADHD symptoms, } \\
\text { conduct problems, } \\
\text { inattention, } \\
\text { oppositional, sleepiness }\end{array}$ & \\
\hline Blunden et al ${ }^{166}$ & $\begin{array}{l}\text { I I snorers }(9.4 \pm \text { I } .2 \mathrm{y}) \\
9 \text { snorers + behavioral } \\
\text { sleep problems }(9.4 \pm \\
\text { I.2 y), I } 3 \text { behavioral sleep } \\
\text { problems }(9.4 \pm \text { I.2 y), } \\
3 \text { I controls }(9.4 \pm \text { I. } 2 \text { y) }\end{array}$ & Questionnaire & Attention, verbal IQ & $\begin{array}{l}\text { Externalizing, } \\
\text { internalizing }\end{array}$ & \\
\hline Carvalho et al ${ }^{167}$ & $\begin{array}{l}79 \text { SDB }(9.4 \pm \mathrm{I} .2 \mathrm{y}), 468 \\
\text { nonrespiratory sleep } \\
\text { disorders }(9.4 \pm \mathrm{I} .2 \mathrm{y}) \\
633 \text { controls }(9.4 \pm \mathrm{I} .2 \mathrm{y})\end{array}$ & Questionnaire & Visual-motor ability & NA & \\
\hline Chervin $^{168}$ & $\begin{array}{l}229 \text { children from clinics } \\
(10.6 \pm 3.1 \text { y), } 28 \text { habitual } \\
\text { snorers }\end{array}$ & Questionnaire & NA & Hyperactive & \\
\hline Goodwin et al ${ }^{169}$ & $\begin{array}{l}480 \text { school students } \\
(9.4 \pm 1.2 \text { y), } \\
\text { II } 5 \text { SDB }(R D I \geq I)\end{array}$ & $\begin{array}{l}\text { Unattended } \\
\text { home PSG }\end{array}$ & Learning problems & Sleepiness & $\begin{array}{l}\text { Nonvalidated } \\
\text { behavior measure }\end{array}$ \\
\hline $\begin{array}{l}\text { Montgomery- } \\
\text { Downs et al }\end{array}$ & $\begin{array}{l}19 \text { OSAS }(4.2 \pm 0.8 y) \\
19 \text { controls }(4.3 \pm 0.7 y)\end{array}$ & PSG, questionnaire & IQ, verbal fluency & NA & \\
\hline Mulvaney et $\mathrm{al}^{63}$ & $\begin{array}{l}403 \text { school students } \\
(9.4 \pm 1.2 \text { y), } 63 \mathrm{SDB} \\
340 \text { controls }\end{array}$ & $\begin{array}{l}\text { Unattended } \\
\text { home PSG }\end{array}$ & NA & $\begin{array}{l}\text { ADHD symptoms, } \\
\text { aggressive, emotional } \\
\text { lability, inattention, } \\
\text { oppositional, social } \\
\text { problems, thought } \\
\text { problems }\end{array}$ & $\begin{array}{l}\text { Controls } \\
\text { displayed } \\
\text { significant } \\
\text { respiratory } \\
\text { disturbance }\end{array}$ \\
\hline
\end{tabular}


Appendix A (Continued)

\begin{tabular}{|c|c|c|c|c|c|}
\hline Authors & Population & $\begin{array}{l}\text { SDB/snoring } \\
\text { measure }\end{array}$ & $\begin{array}{l}\text { Neurocognitive } \\
\text { dysfunction }\end{array}$ & $\begin{array}{l}\text { Behavioral } \\
\text { dysfunction }\end{array}$ & Note \\
\hline Sogut et al ${ }^{170}$ & $\begin{array}{l}\text { I,I } 98 \text { school children } \\
(8.1 \pm 1.9 y), 39 \text { habitual } \\
\text { snorers }\end{array}$ & $\begin{array}{l}\text { PSG (28 snorers), } \\
\text { questionnaire }\end{array}$ & School grades & Sleepiness & $\begin{array}{l}\text { Nonvalidated } \\
\text { behavior measure }\end{array}$ \\
\hline Tran et $\mathrm{al}^{78}$ & $\begin{array}{l}42 \text { children scheduled } \\
\text { for AT }(5.8 \pm 2.5 y) \text {, } \\
4 \text { I children scheduled } \\
\text { for unrelated surgery } \\
(7.3 \pm 3.8 \text { y) }\end{array}$ & PSG (AT group only) & NA & $\begin{array}{l}\text { Presurgery comparisons } \\
\text { not made, but all mean } \\
\text { scores within normal } \\
\text { range for both groups }\end{array}$ & $\begin{array}{l}\text { No PSG for } \\
\text { control }\end{array}$ \\
\hline Urschitz et al ${ }^{|7|}$ & $\begin{array}{l}995 \text { school students } \\
(9.6 \pm 0.7 \text { y, } 99 \text { habitual } \\
\text { snorers })\end{array}$ & $\begin{array}{l}\text { Questionnaire, } \\
\text { home nocturnal } \\
\text { oximetry }\end{array}$ & Mathematical ability & NA & \\
\hline Chervin et $\mathrm{al}^{43}$ & $\begin{array}{l}78 \text { children scheduled for } \\
\text { adenotonsillectomy } \\
(8.1 \pm 1.8 \mathrm{y}), 27 \text { controls } \\
(9.3 \pm 2.0 \mathrm{y})\end{array}$ & $\begin{array}{l}\text { Esophageal } \\
\text { pressure, PSG, } \\
\text { questionnaire }\end{array}$ & Attention & $\begin{array}{l}\text { ADHD symptoms, } \\
\text { hyperactive, sleepiness }\end{array}$ & $\begin{array}{l}\text { Some controls } \\
\text { demonstrated } \\
\text { SDB }\end{array}$ \\
\hline Emancipator et al ${ }^{172}$ & $\begin{array}{l}\text { I } 64 \text { SDB }(9.4 \pm 0.8 y) \\
67 \text { I non-SDB }(9.4 \pm 0.8 y) \text {, } \\
\text { all children from } \\
\text { community sample }\end{array}$ & $\begin{array}{l}\text { Limited PSG, } \\
\text { questionnaire }\end{array}$ & $\begin{array}{l}\text { Executive function, } \\
\text { information } \\
\text { processing, language } \\
\text { comprehension, } \\
\text { verbal problem } \\
\text { solving }\end{array}$ & NA & \\
\hline Galland et $\mathrm{al}^{32}$ & $\begin{array}{l}6 \mathrm{I} \text { children scheduled } \\
\text { for adenotonsillectomy } \\
(7.0 \pm 2.0 \mathrm{y})\end{array}$ & $\begin{array}{l}\text { Limited PSG, } \\
\text { questionnaire }\end{array}$ & $\begin{array}{l}\text { Attention, } \\
\text { impulsivity }\end{array}$ & $\begin{array}{l}\text { Aggression, depression, } \\
\text { hyperactive, inattention, } \\
\text { somatic complaints }\end{array}$ & No control group \\
\hline Halbower et $\mathrm{al}^{52}$ & $\begin{array}{l}19 \text { OSAS }(10.0 \pm 2.5 y) \\
12 \text { controls }(9.8 \pm 2.6 y)\end{array}$ & PSG & $\begin{array}{l}\text { Executive } \\
\text { function, IQ }\end{array}$ & NA & $\begin{array}{l}\text { 5/19 OSAS } \\
\text { children had } \\
\text { ADHD } \\
\text { diagnosis }\end{array}$ \\
\hline Hill et $\mathrm{al}^{33}$ & $\begin{array}{l}21 \text { scheduled for } \\
\text { adenotonsillectomy } \\
(5.5 \pm 1.3 \mathrm{y}), 17 \text { controls } \\
(5.5 \pm \mathrm{I} .4 \mathrm{y})\end{array}$ & $\begin{array}{l}\text { PSG (SDB only), } \\
\text { questionnaire }\end{array}$ & $\begin{array}{l}\text { Attention, } \\
\text { processing speed }\end{array}$ & NA & $\begin{array}{l}\text { No PSG for } \\
\text { control }\end{array}$ \\
\hline Kurnatowski et al ${ }^{34}$ & $\begin{array}{l}\text { I I } 7 \text { SDB }(9.4 \pm 1.2 y) \\
104 \text { controls }(9.4 \pm 1.2 y)\end{array}$ & PSG & $\begin{array}{l}\text { Attention, executive } \\
\text { function, memory, } \\
\text { verbal comprehension, } \\
\text { visuospatial }\end{array}$ & NA & $\begin{array}{l}30 \% \text { controls } \\
\text { demonstrated } \\
\text { snoring }\end{array}$ \\
\hline Li et $\mathrm{al}^{53}$ & $\begin{array}{l}40 \text { referred for } \\
\text { adenotonsillar } \\
\text { hypertrophy }(8.4 \pm 1.6 \mathrm{y})\end{array}$ & PSG & Attention & $\begin{array}{l}\text { No association } \\
\text { with SDB severity }\end{array}$ & No control group \\
\hline Mitchell and Kelly ${ }^{64}$ & 23 OSAS $(9.4 \pm 1.2 y)$ & PSG & NA & Somatic complaints & No control group \\
\hline Suratt et $\mathrm{al}^{59}$ & $\begin{array}{l}\text { I } 14 \text { with adenotonsillar } \\
\text { hypertrophy } \\
(8.5 \pm 1.9 \text { y) }\end{array}$ & PSG, questionnaire & $\begin{array}{l}\text { Verbal reasoning, } \\
\text { vocabulary }\end{array}$ & Somatic complaints & No control group \\
\hline Ziliotto et $\mathrm{al}^{54}$ & $\begin{array}{l}10 \text { oral breathing and } \\
\text { SDB }(7.6 \mathrm{y}), 10 \text { oral } \\
\text { breathing and SDB } \\
(8.1 \mathrm{y}), 10 \text { controls }(7.5 \mathrm{y})\end{array}$ & $\begin{array}{l}\text { PSG (oral breathing } \\
\text { groups only) }\end{array}$ & $\begin{array}{l}\text { Memory for sounds } \\
\text { (auditory processing) }\end{array}$ & NA & $\begin{array}{l}\text { No PSG for } \\
\text { control }\end{array}$ \\
\hline Constantin et $\mathrm{al}^{65}$ & $\begin{array}{l}\text { I } 38 \text { sleep clinic patients } \\
(5.5 \pm 3.0 \mathrm{y})\end{array}$ & PSG & NA & $\begin{array}{l}\text { No difference between } \\
\text { OSAS and non-OSAS }\end{array}$ & $\begin{array}{l}\text { Retrospective } \\
\text { behavior } \\
\text { assessment, no } \\
\text { control group }\end{array}$ \\
\hline Dillon et $\mathrm{al}^{66}$ & $\begin{array}{l}78 \text { children scheduled for } \\
\text { adenotonsillectomy } \\
(8.1 \pm 1.8 \mathrm{y}), 27 \text { controls } \\
(9.3 \pm 2.0 \mathrm{y})\end{array}$ & PSG & NA & $\begin{array}{l}\text { ADHD symptoms, } \\
\text { oppositional }\end{array}$ & $\begin{array}{l}\text { Some controls } \\
\text { demonstrated } \\
\text { SDB }\end{array}$ \\
\hline
\end{tabular}


Appendix A (Continued)

\begin{tabular}{|c|c|c|c|c|c|}
\hline Authors & Population & $\begin{array}{l}\text { SDB/snoring } \\
\text { measure }\end{array}$ & $\begin{array}{l}\text { Neurocognitive } \\
\text { dysfunction }\end{array}$ & $\begin{array}{l}\text { Behavioral } \\
\text { dysfunction }\end{array}$ & Note \\
\hline Gozal et $\mathrm{al}^{55}$ & $\begin{array}{l}102 \text { OSAS }(6.4 \pm 0.4 y), \\
103 \text { snorers }(6.6 \pm 0.3 y), \\
73 \text { controls }(6.3 \pm 0.3 y)\end{array}$ & PSG, questionnaire & $\begin{array}{l}\text { Global cognitive } \\
\text { ability }\end{array}$ & NA & $\begin{array}{l}\text { Specific cognitive } \\
\text { domains not } \\
\text { specified }\end{array}$ \\
\hline Hiscock et al ${ }^{173}$ & $\begin{array}{l}4,983 \text { communities } \\
(4.7 \pm 0.2 y)\end{array}$ & Questionnaire & Verbal ability & Conduct problems & \\
\hline Uema et $\mathrm{al}^{56}$ & $\begin{array}{l}24 \text { OSAS, } 37 \text { primary } \\
\text { snorers, } 20 \text { controls } \\
(\text { all } 6-12 \text { y) }\end{array}$ & PSG & Verbal memory & NA & $\begin{array}{l}\text { Deficits in both } \\
\text { OSAS and } \\
\text { primary snorers }\end{array}$ \\
\hline Wei et $a^{88}$ & $\begin{array}{l}\text { I I } 7 \text { referred for } \\
\text { adenotonsillectomy } \\
(6.5 \pm 1.8 \mathrm{y})\end{array}$ & Questionnaire & NA & $\begin{array}{l}\text { ADHD-type behavior, } \\
\text { inattention, oppositional }\end{array}$ & $\begin{array}{l}\text { No control group, } \\
\text { no comparison } \\
\text { with standard } \\
\text { norms }\end{array}$ \\
\hline Giordani et $\mathrm{al}^{25}$ & $\begin{array}{l}40 \text { OSAS scheduled } \\
\text { for adenotonsillectomy } \\
(7.8 \pm 1.8 \mathrm{y}), 38 \text { non- } \\
\text { OSAS scheduled for } \\
\text { adenotonsillectomy } \\
(8.4 \pm 1.8 \mathrm{y}), 26 \text { controls } \\
(9.2 \pm 2.0 \mathrm{y})\end{array}$ & PSG & $\begin{array}{l}\text { OSAS: attention, } \\
\text { mathematical ability, } \\
\text { visual memory, } \\
\text { visuospatial; non- } \\
\text { OSAS: mathematical } \\
\text { ability,visual memory, } \\
\text { visuospatial }\end{array}$ & $\begin{array}{l}\text { Externalizing, } \\
\text { hyperactivity, } \\
\text { internalizing }\end{array}$ & $\begin{array}{l}\text { Controls from } \\
\text { unrelated surgery } \\
\text { clinic }\end{array}$ \\
\hline Karpinski et al ${ }^{174}$ & $\begin{array}{l}39 \text { preschool students } \\
(4.3 \pm 0.6 \mathrm{y})\end{array}$ & Questionnaire & Executive function & NA & $\begin{array}{l}\text { Only } 6 \text { snoring } \\
\text { children }\end{array}$ \\
\hline Moré et al ${ }^{82}$ & 73 snorers $(4.6 \pm 2.0 y)$ & $\begin{array}{l}\text { Questionnaire, } \\
\text { PSG (6I children) }\end{array}$ & Memory & Aggression & $\begin{array}{l}\text { No control group, } \\
\text { no comparison } \\
\text { with standard } \\
\text { norms }\end{array}$ \\
\hline Zhao et $\mathrm{al}^{30}$ & $\begin{array}{l}403 \text { communities } \\
(8.3 \pm 1.6 y)\end{array}$ & $\begin{array}{l}\text { Unattended } \\
\text { home PSG }\end{array}$ & NA & $\begin{array}{l}\text { Aggression/ } \\
\text { oppositional, social } \\
\text { problems, somatic } \\
\text { complaints }\end{array}$ & $\begin{array}{l}\text { Deficits } \\
\text { irrespective of } \\
\text { hypoxia severity }\end{array}$ \\
\hline Aronen et $\mathrm{al}^{175}$ & $\begin{array}{l}43 \text { snorers }(4.9 \pm I . I y) \\
46 \text { controls }(4.8 \pm I . I y)\end{array}$ & Questionnaire & $\begin{array}{l}\text { Auditory attention, } \\
\text { language } \\
\text { development, } \\
\text { verbal ability }\end{array}$ & $\begin{array}{l}\text { Anxiety, emotional } \\
\text { lability }\end{array}$ & $\begin{array}{l}\text { Not all children } \\
\text { included in } \\
\text { analyses of } \\
\text { language and } \\
\text { attention }\end{array}$ \\
\hline Calhoun et $\mathrm{al}^{57}$ & $\begin{array}{l}57 \mathrm{I} \text { communities } \\
(4 \mathrm{I} 3 \text { controls, } 8.7 \pm \mathrm{I} .6 \mathrm{y} \\
\text { I58 SDB, } 8.7 \pm \mathrm{I} .7 \mathrm{y})\end{array}$ & PSG & $\begin{array}{l}\text { Nonverbal IQ } \\
\text { (snoring + OSA vs } \\
\text { nonsnoring + no OSA) }\end{array}$ & NA & \\
\hline Ericsson et al ${ }^{89}$ & $\begin{array}{l}67 \text { referred for tonsillar } \\
\text { hypertrophy (all } 4.5-5.5 \text { y) }\end{array}$ & None & NA & Internalizing & $\begin{array}{l}\text { No control group, } \\
\text { no measure of } \\
\text { SDB }\end{array}$ \\
\hline Gozal et $\mathrm{al}^{58}$ & $\begin{array}{l}87 \text { OSAS }(6.4 \pm 0.5 y) \\
52 \text { controls }(6.1 \pm 0.4 y)\end{array}$ & PSG & $\begin{array}{l}\text { Executive function, } \\
\text { language } \\
\text { development, } \\
\text { mathematical } \\
\text { ability, verbal ability }\end{array}$ & NA & \\
\hline Kohler et al ${ }^{18}$ & $\begin{array}{l}44 \operatorname{SDB}(6.6 \pm 2.6 y) \\
48 \text { controls }(7.7 \pm 2.6 y)\end{array}$ & PSG & $\begin{array}{l}\text { Executive function, IQ, } \\
\text { language development, } \\
\text { sensorimotor, verbal } \\
\text { memory, visuospatial }\end{array}$ & NA & \\
\hline Lundeborg et $\mathrm{al}^{83}$ & $\begin{array}{l}67 \text { referred for tonsillar } \\
\text { hypertrophy }(4.8 \pm 0.4 \mathrm{y}) \text {, } \\
47 \text { controls }(4.8 \pm 0.4 \mathrm{y})\end{array}$ & None & $\begin{array}{l}\text { Language } \\
\text { development } \\
\text { (phonological } \\
\text { processing) }\end{array}$ & NA & $\begin{array}{l}\text { No measure of } \\
\text { SDB }\end{array}$ \\
\hline
\end{tabular}

Abbreviations: AT, adenotonsillectomy; SDB, sleep-disordered breathing; OSAS, obstructive sleep apnea syndrome; PSG, polysomnography; TcCO ${ }_{2}$, transcutaneous $\mathrm{CO}_{2}$ monitoring; IQ, intelligence quotient; NA, not assessed. 
Appendix B Summary of published studies investigating changes in neurocognitive performance and behavior following treatment for SDB amongst children

\begin{tabular}{|c|c|c|c|c|c|c|c|}
\hline Study & $\begin{array}{l}\text { Baseline } \\
\text { population }\end{array}$ & $\begin{array}{l}\text { Follow-up } \\
\text { population }\end{array}$ & $\begin{array}{l}\text { SDB } \\
\text { measure }\end{array}$ & Intervention & $\begin{array}{l}\text { Follow-up } \\
\text { period }\end{array}$ & $\begin{array}{l}\text { Neurocognitive } \\
\text { effects }\end{array}$ & Behavior effects \\
\hline $\begin{array}{l}\text { Guilleminault } \\
\text { et al }{ }^{6}\end{array}$ & 8 OSAS & 7 OSAS & PSG & $\begin{array}{l}\text { AT }(n=5), \\
\text { tracheotomy } \\
(n=2)\end{array}$ & $\begin{array}{l}3 \text { and } 6 \text { wk (AT), } \\
22 \text { and } 28 \text { mo } \\
\text { (tracheotomy) }\end{array}$ & $\begin{array}{l}\text { 个School } \\
\text { performance }\end{array}$ & $\downarrow$ Daytime sleepiness \\
\hline $\begin{array}{l}\text { Brouillette } \\
\text { et } \mathrm{al}^{68}\end{array}$ & 22 OSAS & 22 OSAS & $\begin{array}{l}\text { Daytime or } \\
\text { nighttime } \\
\text { PSG }\end{array}$ & $\begin{array}{l}\text { Adenoidectomy } \\
\text { and/or } \\
\text { tonsillectomy } \\
(\mathrm{n}=\mathrm{II}) \\
\text { tracheotomy } \\
(\mathrm{n}=\mathrm{II})\end{array}$ & Not specified & NA & $\begin{array}{l}\downarrow \text { Daytime sleepiness and } \\
\downarrow \text { behavioral disturbance } \\
(\mathrm{n}=5)\end{array}$ \\
\hline $\begin{array}{l}\text { Guilleminault } \\
\text { et } \mathrm{al}^{7}\end{array}$ & $\begin{array}{l}25 \text { snorers, } \\
25 \text { controls }\end{array}$ & 25 snorers & $\begin{array}{l}\text { PSG, } \\
\text { esophageal } \\
\text { pressure }\end{array}$ & $\begin{array}{l}\text { AT } \\
\text { (snoring only) }\end{array}$ & $12 \mathrm{mo}$ & $\begin{array}{l}\uparrow \text { School } \\
\text { performance } \\
\text { (by } 3 \text { mo), } \\
\text { 个attention }(n=5)\end{array}$ & $\begin{array}{l}\downarrow \text { Hyperactivity (by } \\
6 \text { mo), } \downarrow \text { daytime } \\
\text { sleepiness }(n=5)\end{array}$ \\
\hline $\begin{array}{l}\text { Stradling } \\
\text { et } \mathrm{al}^{71}\end{array}$ & $\begin{array}{l}61 \text { snorers, } \\
31 \text { controls }\end{array}$ & $\begin{array}{l}58 \text { snorers, } \\
31 \text { controls }\end{array}$ & $\begin{array}{l}\text { Oximetry, } \\
\text { video } \\
\text { ( } 26 \text { snorers } \\
\text { and } \\
27 \text { controls) }\end{array}$ & $\begin{array}{l}\text { AT } \\
\text { (snoring only) }\end{array}$ & $6 \mathrm{mo}$ & NA & $\begin{array}{l}\downarrow \text { Hyperactivity } \\
\text { and } \downarrow \text { aggression/ } \\
\text { rebelliousness }\end{array}$ \\
\hline Ali et a $\mathrm{l}^{70}$ & $\begin{array}{l}\text { I } 2 \text { SDB, } \\
\text { II snorers, } \\
\text { I0 controls }\end{array}$ & $\begin{array}{l}\text { I } 2 \text { SDB, } \\
\text { II snorers, } \\
\text { I0 controls }\end{array}$ & $\begin{array}{l}\text { Oximetry, } \\
\text { video }\end{array}$ & $\begin{array}{l}\text { AT (SDB and } \\
\text { snoring only) }\end{array}$ & $3-4$ mo & $\begin{array}{l}\text { SDB: } \uparrow \text { vigilance, } \\
\text { no difference in } \\
\text { impulsivity; snoring: } \\
\text { no difference in } \\
\text { impulsivity }\end{array}$ & $\begin{array}{l}\text { SDB: } \downarrow \text { aggression, } \\
\text { inattention and } \\
\text { hyperactivity; snoring: } \\
\downarrow \text { Hyperactivity }\end{array}$ \\
\hline Gozal $^{72}$ & $\begin{array}{l}\text { I } 20 \text { SDB, } \\
\text { I77 controls }\end{array}$ & $\begin{array}{l}\text { I } 20 \text { SDB, } \\
\text { I77 controls }\end{array}$ & $\begin{array}{l}\text { Oximetry, } \\
\mathrm{TcCO}_{2}\end{array}$ & $\begin{array}{l}\text { AT } \\
\text { (24 SDB only) }\end{array}$ & $15 \mathrm{mo}$ & $\begin{array}{l}\uparrow \text { Academic } \\
\text { performance in } \\
\text { treated SDB } \\
\text { children }\end{array}$ & NA \\
\hline Harvey et al ${ }^{80}$ & $56 \mathrm{SDB}$ & $42 \mathrm{SDB}$ & PSG & $\begin{array}{l}\text { AT } \\
\text { (24 SDB only) }\end{array}$ & $6 \mathrm{mo}$ & $\begin{array}{l}\text { No change in } \\
\text { mental development }\end{array}$ & NA \\
\hline $\begin{array}{l}\text { Goldstein } \\
\text { et } \mathrm{al}^{85}\end{array}$ & $36 \mathrm{SDB}$ & 15 SDB & Questionnaire & AT & $3 \mathrm{mo}$ & NA & $\begin{array}{l}\downarrow \text { Internalizing, } \\
\text { withdrawn and somatic } \\
\text { complaints, anxiety, } \\
\text { depression, inattention } \\
\text { and hyperactivity }\end{array}$ \\
\hline Owens et $\mathrm{al}^{46}$ & 18 OSAS & 8 OSAS & PSG & AT & $\sim 7 \mathrm{mo}$ & $\begin{array}{l}\text { TExecutive function, } \\
\text { } \text { motor skills; } \\
\text { no change in IQ, } \\
\text { language, memory, } \\
\text { visual perception/ } \\
\text { motor ability }\end{array}$ & $\begin{array}{l}\text { No change in } \\
\text { internalizing, } \\
\text { externalizing, and } \\
\text { somatic complaints, } \\
\text { attention, anxiety, } \\
\text { hyperactivity }\end{array}$ \\
\hline $\begin{array}{l}\text { Richards and } \\
\text { Ferdman }{ }^{73}\end{array}$ & NA & 45 OSAS & $\begin{array}{l}\text { PSG, } \\
\text { questionnaire }\end{array}$ & AT & $6-18 \mathrm{mo}$ & $\begin{array}{l}\text { Poor school } \\
\text { performance } \\
\text { despite treatment }\end{array}$ & $\begin{array}{l}\text { Daytime sleepiness } \\
\text { despite treatment }\end{array}$ \\
\hline $\begin{array}{l}\text { Hansen and } \\
\text { Vandenberg }\end{array}$ & $\begin{array}{l}7 \text { OSAS, } \\
7 \text { narcoleptics }\end{array}$ & $\begin{array}{l}7 \text { OSAS, } \\
7 \text { narcoleptics }\end{array}$ & PSG & $\begin{array}{l}\text { Unspecified } \\
\text { surgery and } \\
\text { CPAP } \\
\text { (OSAS only) }\end{array}$ & Not specified & 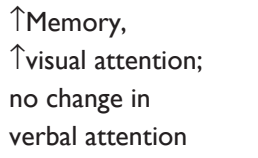 & NA \\
\hline $\begin{array}{l}\text { Goldstein } \\
\text { et } \mathrm{al}^{84}\end{array}$ & 64 OSAS & 64 OSAS & $\begin{array}{l}\text { Clinical history, } \\
\text { physical } \\
\text { examination }\end{array}$ & AT & $3 \mathrm{mo}$ & NA & $\begin{array}{l}\text { \Internalizing, } \\
\text { externalizing, } \\
\text { withdrawn, and somatic } \\
\text { complaints, anxiety, } \\
\text { depression, inattention } \\
\text { and aggression }\end{array}$ \\
\hline
\end{tabular}

(Continued) 
Appendix B (Continued)

\begin{tabular}{|c|c|c|c|c|c|c|c|}
\hline Study & $\begin{array}{l}\text { Baseline } \\
\text { population }\end{array}$ & $\begin{array}{l}\text { Follow-up } \\
\text { population }\end{array}$ & $\begin{array}{l}\text { SDB } \\
\text { measure }\end{array}$ & Intervention & $\begin{array}{l}\text { Follow-up } \\
\text { period }\end{array}$ & $\begin{array}{l}\text { Neurocognitive } \\
\text { effects }\end{array}$ & Behavior effects \\
\hline $\begin{array}{l}\text { Friedman } \\
\text { et } \text { al }^{16}\end{array}$ & $\begin{array}{l}39 \text { OSAS, } \\
20 \text { controls }\end{array}$ & $\begin{array}{l}27 \text { OSAS, } \\
14 \text { controls }\end{array}$ & $\begin{array}{l}\text { PSG } \\
\text { (OSAS only), } \\
\text { questionnaire }\end{array}$ & $\begin{array}{l}\text { AT } \\
\text { (OSAS only) }\end{array}$ & $6-10 \mathrm{mo}$ & $\begin{array}{l}\text { } \text { Analytic thinking, } \\
\text { perceptual ability, } \\
\text { visuospatial ability, } \\
\text { intelligence, verbal } \\
\text { memory; no change } \\
\text { in vocabulary and } \\
\text { memory for numbers }\end{array}$ & NA \\
\hline Avior et $\mathrm{al}^{79}$ & 19 OSAS & 19 OSAS & $\begin{array}{l}\text { Questionnaire, } \\
\text { physical } \\
\text { examination }\end{array}$ & AT & $2 \mathrm{mo}$ & 个Attention & 个Attention \\
\hline $\begin{array}{l}\text { Montgomery- } \\
\text { Downs et al }\end{array}$ & $\begin{array}{l}19 \text { OSAS, } \\
19 \text { controls }\end{array}$ & 19 OSAS & $\begin{array}{l}\text { PSG, } \\
\text { questionnaire }\end{array}$ & $\begin{array}{l}\text { AT } \\
\text { (OSAS only) }\end{array}$ & $3-6 \mathrm{mo}$ & $\begin{array}{l}\text { 个IQ; no change } \\
\text { for language } \\
\text { development }\end{array}$ & NA \\
\hline Tran et $\mathrm{al}^{78}$ & $\begin{array}{l}42 \text { OSAS, } \\
41 \text { controls }\end{array}$ & $\begin{array}{l}42 \text { OSAS, } \\
41 \text { controls }\end{array}$ & $\begin{array}{l}\text { PSG } \\
\text { (OSAS only) }\end{array}$ & $\begin{array}{l}\text { AT } \\
\text { (OSAS only) }\end{array}$ & $3 \mathrm{mo}$ & NA & $\begin{array}{l}\downarrow \text { Internalizing, thought } \\
\text { problems and somatic } \\
\text { complaints; no change } \\
\text { in externalizing and } \\
\text { withdrawn behavior, } \\
\text { inattention, aggression, } \\
\text { anxiety or depression }\end{array}$ \\
\hline $\begin{array}{l}\text { Chervin } \\
\text { et } \mathrm{al}^{43}\end{array}$ & $\begin{array}{l}78 \text { SDB, } 27 \\
\text { controls }\end{array}$ & $\begin{array}{l}77 \text { SDB, } \\
23 \text { controls }\end{array}$ & PSG & AT & $12 \mathrm{mo}$ & 个Attention & $\begin{array}{l}\downarrow \text { Hyperactivity and } \\
\text { sleepiness }\end{array}$ \\
\hline Galland et $\mathrm{al}^{32}$ & $\begin{array}{l}61 \text { suspected } \\
\text { SDB or } \\
\text { tonsillitis }\end{array}$ & $\begin{array}{l}61 \text { suspected } \\
\text { SDB or } \\
\text { tonsillitis }\end{array}$ & $\begin{array}{l}\text { Limited PSG, } \\
\text { questionnaire }\end{array}$ & AT & $3 \mathrm{mo}$ & $\begin{array}{l}\text { } V \text { isual attention; } \\
\text { no change for } \\
\text { auditory attention }\end{array}$ & $\begin{array}{l}\downarrow \text { Internalizing, } \\
\text { externalizing and } \\
\text { somatic complaints, } \\
\text { inattention, } \\
\text { hyperactivity, aggression } \\
\text { and anxiety }\end{array}$ \\
\hline Li et $a^{53}$ & $\begin{array}{l}40 \text { suspected } \\
\text { SDB }\end{array}$ & $\begin{array}{l}40 \text { suspected } \\
\text { SDB }\end{array}$ & PSG & AT & $6 \mathrm{mo}$ & 个Attention & $\begin{array}{l}\downarrow \text { Internalizing, } \\
\text { externalizing and } \\
\text { somatic complaints, } \\
\text { inattention, depression, } \\
\text { hyperactivity and } \\
\text { anxiety; no change in } \\
\text { aggression }\end{array}$ \\
\hline $\begin{array}{l}\text { Mitchell } \\
\text { and Kelly }{ }^{64}\end{array}$ & 23 OSAS & 23 OSAS & PSG & AT & $\begin{array}{l}6 \mathrm{mo} \text { and } \\
9-18 \mathrm{mo}\end{array}$ & NA & $\begin{array}{l}\downarrow \text { Internalizing, } \\
\text { externalizing and } \\
\text { somatic complaints, } \\
\text { depression, hyperactivity } \\
\text { and aggression }\end{array}$ \\
\hline $\begin{array}{l}\text { Roemmich } \\
\text { et } \mathrm{al}^{86}\end{array}$ & 54 OSAS & 54 OSAS & PSG & AT & $12 \mathrm{mo}$ & NA & $\downarrow$ Hyperactivity \\
\hline $\begin{array}{l}\text { Constantin } \\
\text { et } \mathrm{al}^{65}\end{array}$ & 94 SDB & 94 SDB & PSG & AT $(n=54)$ & $\begin{array}{l}\sim 4 \text { y } \\
\text { (retrospective } \\
\text { reports only) }\end{array}$ & NA & $\begin{array}{l}\text { No change in } \\
\text { oppositional behavior, } \\
\text { inattention and } \\
\text { hyperactivity }\end{array}$ \\
\hline Dillon et $\mathrm{al}^{66}$ & $\begin{array}{l}79 \text { SDB, } \\
27 \text { controls }\end{array}$ & $\begin{array}{l}78 \text { SDB, } \\
23 \text { controls }\end{array}$ & PSG & AT & $12 \mathrm{mo}$ & NA & $\begin{array}{l}\downarrow \text { Oppositional behavior; } \\
\text { however, differences } \\
\text { still evident post-AT; no } \\
\text { change in anxiety and } \\
\text { depression; } \downarrow \text { inattention } \\
\text { and hyperactivity no } \\
\text { greater than for controls }\end{array}$ \\
\hline
\end{tabular}

(Continued) 
Appendix B (Continued)

\begin{tabular}{|c|c|c|c|c|c|c|c|}
\hline Study & $\begin{array}{l}\text { Baseline } \\
\text { population }\end{array}$ & $\begin{array}{l}\text { Follow-up } \\
\text { population }\end{array}$ & $\begin{array}{l}\text { SDB } \\
\text { measure }\end{array}$ & Intervention & $\begin{array}{l}\text { Follow-up } \\
\text { period }\end{array}$ & $\begin{array}{l}\text { Neurocognitive } \\
\text { effects }\end{array}$ & Behavior effects \\
\hline Wei et $a^{88}$ & 117 SDB & 7I SDB & Questionnaire & AT & $6 \mathrm{mo}$ & NA & $\begin{array}{l}\text { \Inattention, } \\
\text { hyperactivity and } \\
\text { oppositional behavior }\end{array}$ \\
\hline Hogan et $\mathrm{al}^{81}$ & $\begin{array}{l}19 \text { SDB, } \\
14 \text { controls }\end{array}$ & $\begin{array}{l}\text { I9 SDB, } \\
14 \text { controls }\end{array}$ & $\begin{array}{l}\text { PSG (SDB, } \\
\text { baseline only), } \\
\text { oximetry and } \\
\text { questionnaire } \\
\text { ( } \mathrm{n}=16 \mathrm{SDB} \text {, } \\
\text { baseline and } \\
\text { follow-up) }\end{array}$ & AT & $\begin{array}{l}\text { I I mo (SDB), } \\
\text { I } 3 \text { mo (control), } \\
P<0.00 \text { I }\end{array}$ & $\begin{array}{l}\uparrow \text { Processing speed; } \\
\text { trend for } \uparrow \text { in visual } \\
\text { attention; no change } \\
\text { for executive } \\
\text { function }\end{array}$ & NA \\
\hline Moré et a ${ }^{82}$ & $73 \mathrm{SDB}$ & 44 SDB & $\begin{array}{l}\text { PSG }(n=29) \text {, } \\
\text { questionnaire }\end{array}$ & AT & $9 \mathrm{mo}$ & $\begin{array}{l}\uparrow \text { Concentration, } \\
\text { memory, school } \\
\text { performance and } \\
\downarrow \text { speech delay } \\
\text { (parent report only) }\end{array}$ & $\begin{array}{l}\downarrow \text { Aggressiveness and } \\
\text { hyperactivity }\end{array}$ \\
\hline $\begin{array}{l}\text { Ericsson } \\
\text { et } \mathrm{al}^{89}\end{array}$ & $67 \mathrm{SDB}$ & 67 SDB & $\begin{array}{l}\text { Clinical } \\
\text { examination }\end{array}$ & $\begin{array}{l}\text { TE }(n=32) \\
\operatorname{TT}(n=35)\end{array}$ & $6 \mathrm{mo}$ & NA & $\begin{array}{l}\text { TE: } \downarrow \text { somatic } \\
\text { complaints, anxiety, } \\
\text { inattention, social } \\
\text { problems (no change } \\
\text { in withdrawn behavior, } \\
\text { aggression, thought } \\
\text { problems); TT: } \downarrow \text { somatic } \\
\text { complaints, aggression } \\
\text { (no change in withdrawn } \\
\text { behavior, anxiety, } \\
\text { inattention, social and } \\
\text { thought problems) }\end{array}$ \\
\hline $\begin{array}{l}\text { Lundeborg } \\
\text { et al }{ }^{83}\end{array}$ & $\begin{array}{l}67 \text { SDB, } \\
47 \text { controls }\end{array}$ & $\begin{array}{l}64 \mathrm{SDB}, \\
31 \text { controls }\end{array}$ & $\begin{array}{l}\text { Clinical } \\
\text { examination }\end{array}$ & $\begin{array}{l}\text { TE }(n=32) \\
\text { TT }(n=35)\end{array}$ & $6 \mathrm{mo}$ & $\begin{array}{l}\text { } \text { Language } \\
\text { development; } \\
\text { however, deficits } \\
\text { still evident } \\
\text { posttreatment }\end{array}$ & NA \\
\hline $\begin{array}{l}\text { Kohler } \\
\text { et al }{ }^{18}\end{array}$ & $\begin{array}{l}44 \text { SDB, } \\
48 \text { controls }\end{array}$ & $\begin{array}{l}44 \text { SDB, } \\
48 \text { controls }\end{array}$ & PSG & AT & $6 \mathrm{mo}$ & $\begin{array}{l}\uparrow \text { Visuospatial ability, } \\
\text { however, deficits still } \\
\text { evident posttreatment; } \\
\text { no change in IQ, } \\
\text { executive function, } \\
\text { attention, language } \\
\text { development, } \\
\text { sensorimotor } \\
\text { function and memory }\end{array}$ & NA \\
\hline Wei et al ${ }^{87}$ & 7I SDB & 44 SDB & Questionnaire & AT & $2.4-3.6 y$ & NA & $\begin{array}{l}\text { \nattention, } \\
\text { hyperactivity, and } \\
\text { oppositional behavior; } \\
\text { no change in ADHD } \\
\text { symptoms }\end{array}$ \\
\hline
\end{tabular}

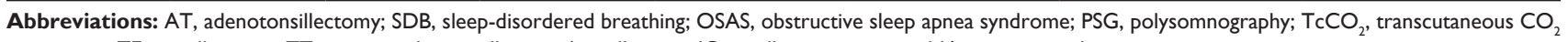
monitoring; TE, tonsillectomy; TT, intracapsular tonsillectomy/tonsillotomy; IQ, intelligence quotient; NA, not assessed.

Nature and Science of Sleep

\section{Publish your work in this journal}

Nature and Science of Sleep is an international, peer-reviewed, open access journal covering all aspects of sleep science and sleep medicine, including the neurophysiology and functions of sleep, the genetics of sleep, sleep and society, biological rhythms, dreaming, sleep disorders and therapy, and strategies to optimize healthy sleep. The journal welcomes

\section{Dovepress}

original research, clinical \& epidemiological studies, reviews \& evaluations, case reports and extended reports. The manuscript management system is completely online and includes a very quick and fair peerreview system, which is all easy to use. Visit http://www.dovepress.com/ testimonials.php to read real quotes from published authors.

Submit your manuscript here: http://www.dovepress.com/nature-and-science-of-sleep-journal 